$27 / 83$

47 热 $7-8945$

Dr. 1346

Atmospheric Release Advisory Capability Pilot Project at

Two Nuclear Power Plants and

Associated State Offices of

Emergency Preparedness

Leonard C. Rosen

UCRL-53280

January 1983






\begin{tabular}{|c|c|}
\hline REPORT DOCUMENTATION PAGE & $\begin{array}{l}\text { READ INSTRUCTIONS } \\
\text { BEFORE COMPLETING FORM }\end{array}$ \\
\hline 2. GOVT ACCESSION NO. & 3. RECIPIENT'S CATALOG NUMBER \\
\hline \multirow{2}{*}{$\begin{array}{l}\text { 4. TITLE (and Subtitlo) } \\
\text { Atmospheric Release Advisory Capability Pilot } \\
\text { Project at Two Nuclear Power Plants and Associated } \\
\text { State Offices of Emergency Preparedness }\end{array}$} & $\begin{array}{l}\text { 5. TYPE OF REPORT A'PERIOD COVERED } \\
\text { Final Report }\end{array}$ \\
\hline & $\begin{array}{l}\text { 6. PERFORMING ORG. REPORT NUMBER } \\
\text { UCRL- } 53280\end{array}$ \\
\hline $\begin{array}{l}\text { 7. AUTHOR(s) } \\
\text { Leonard C. Rosen }\end{array}$ & $\begin{array}{l}\text { 8. CON'SARCT OB GRANT-NUMBER(A) } \\
\text { EMW-E-0555 }\end{array}$ \\
\hline $\begin{array}{l}\text { 9. PERFORMING ORGANIZATION NAME AND ADDRESS } \\
\text { LaWrence Livermore National Laboratory } \\
\text { P. O. Box } 808 \\
\text { Livermore, CA } 94550\end{array}$ & $\begin{array}{l}\text { 10. PROGRAM ELEMENT. PROJECT, TA5K } \\
\text { AREA \& WORK UNIT'NUMBERS } \\
\text { M002 }\end{array}$ \\
\hline \multirow{2}{*}{$\begin{array}{l}\text { 11. CONTROLLING OfFICE NAME AND AdDRESS } \\
\text { Federal Emergency Management Agency } \\
\text { Washington, DC } 20472\end{array}$} & $\begin{array}{l}\text { 12. REPORT DATTE } \\
\text { January } 1983\end{array}$ \\
\hline & $\begin{array}{l}\text { 13. NUMEER OF PAGES } \\
38\end{array}$ \\
\hline \multirow[t]{2}{*}{ 14. MONITORING AGENCY NAME Q ADORESS(If different Irom Controlling Oflice) } & $\begin{array}{l}\text { 15. SECURITY CLASS. (of this roport) } \\
\text { UNCLASSIFIED }\end{array}$ \\
\hline & $\begin{array}{l}\text { 15a. DECLASSIFICATION/DOWNGRADING } \\
\text { SCHEDULE }\end{array}$ \\
\hline \multicolumn{2}{|l|}{$\begin{array}{l}\text { 16. DISTRIEUTION STATEMEN T fof thls Roport) } \\
\text { Approved for Public Release, Distribution Unlimited }\end{array}$} \\
\hline \multicolumn{2}{|l|}{ 17. DISTRIBUTION STATEMENT (af the abatract oxitorad In Block 20, It diflerent from Report) } \\
\hline \multicolumn{2}{|l|}{ 18. SUPPLEMENTARY NOTES } \\
\hline \multicolumn{2}{|l|}{$\begin{array}{l}\text { 19. KEY wORDS (Continuo on ravorso alde If nocasaary and ldantify by block number) } \\
\text { air concentrations } \\
\text { emergency response } \\
\text { site facility }\end{array}$} \\
\hline 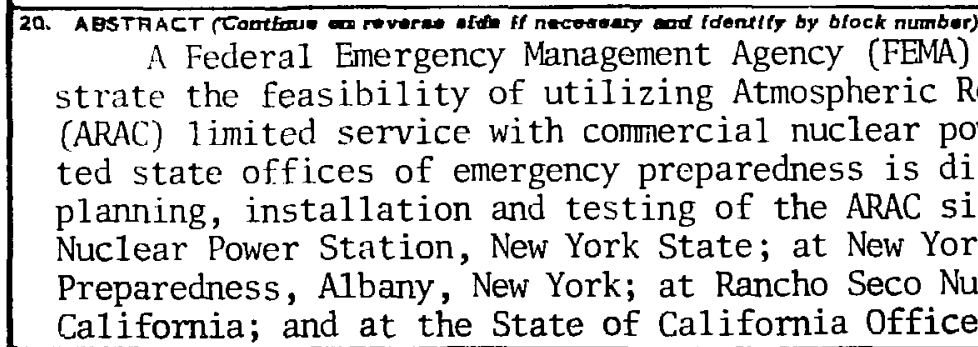 & $\begin{array}{l}\text { sponsored project to demon- } \\
\text { elease Advisory Capability } \\
\text { wer plants and their associa- } \\
\text { scussed herein. Preliminary } \\
\text { te facilities at Indian Point } \\
\text { k State Office of Emergency } \\
\text { clear Generating Station, } \\
\text { of Emergency Services, }\end{array}$ \\
\hline
\end{tabular}


20. cont'd.

Sacramento, California, are summarized. ARAC pa.ticipation in the Robert E. Ginna nuclear generating plant accident in New York on January 25, 1982, is discussed. The ARAC system is evaluated with emphasis on communications, the suite of models contained within the ARAC system, and the staff. The implications of this project in designing the next-generation ARAC system to service federal and state needs are assessed. 


\title{
Atmospheric Release Advisory Capability Pilot Project at Two Nuclear Power Plants and Associated State Offices of Emergency Preparedness
}

Leonard C. Rosen

for

Federal Emergency Management Agency

Washington, D. C. 20472

Subcontract EMW-E-0555, work unit M002

Final report, January 1983

\author{
Lawrence Livermore National Laboratory \\ 7000 East Avenue \\ Livermore, CA 94550
}

DISC I.AIMER

\begin{abstract}
I hiv repurt was porepared as an account of work sponsored by an ugency of the 1/nited States (jover rument Nelther the I nited States fovernment nor any agency thereof nur any of thesr cinployeses, makes any wareanty, express or implied, or asiumes ans legal liability or responsihillty for the accuracy. completenciss, or usefulness of any information, apparatus, product, or process dirclosed, in represent: that its tese would not infringe privalely owned rights. Reference herein to any specific comnercial product, process, or service by trade name, trademark, nanufacturer, or otherwise does not necessarily constitute or imply its endorsement, recommendation, or favoring by the United States Guvernment or any agency thereof. The views and opinions of authors expressed hercin do not neccssarily state or reflect those of the Unted States Government or any agency thereof.
\end{abstract}

\section{NoTIGE}

PORTIONS OF THIS REPORT ARE ILLEEIBLE.

It has been reproduced from the best available copy to permil the broabet possible avallabliky. 


\title{
ATMOSPHERIC スELEASE ADVISORY CAPABILITY PILOT PROJECT \\ AT TWO NUCLEAR POWER PLANTS AND \\ ASSOCIATED STATE OFFICES OF EMERGENCY PREPAREDNESS
}

\author{
Detachable Summary
}

The Federal Emergency Management Agency (FEMA) has supported a pilot project with the Lawrence Livermore National Laboratory (LLNL) to demonstrate the feasibility of utilizing Atmospheric Release Advisory Capability (ARAC) limited service with commercial nuclear power plants and to provide a basis for considering more extensive applications of the ARAC system on a national scale.

ARAC site facility terminals were installed in the fall of 1980 at Indian Point Nuclear Power Station, New York State, and at the New York State Office of Emergency Preparedness, Albany. Site systems were also installed in the spring of 1981 at Rancho Seco Nuclear Generating Station, California, and at the State of California, Office of Emergency Services, Sacramento. Following the installations, a training program was instituted that incorporated both formal meetings at $L L N L$ and on-the-job training through a series of four exercises. The exercises were designed to give site system users realistic training so that, on completion of the fourth and final exercise, each utility and its associated state office would be competent to use the ARAC system jointly in case of an actual nuclear accident. Testing for the New York installation was completed on September 25, 1981, and on January 19, 1982, for the California sites. After each exercise, the staffs of the various sites sent written critiques of the exercise to the ARAC staff for use in evaluating the system und for future training and system design (see Appendix A). The ARAC staff also prepared a training tape, delivered October 29, 1981, for training site system personnel or for use in an emergency preparedness exercise. The ARAC system was used during the Ginna nuclear accident of January 25, 1982, when personnel from ARAC and New York State quickly combined resources to assess the consequence of the accident and again with both New York sites for a FEMA/In dian Point exercise on March 3, 1982.

Site demonstrations of the ARAC system have shown it to be feasible and earned it commendations and incorporation into the emergency preparedness plans of New York and California, as demonstrated by the following:

- The two state offices and Rancho Seco Nuclear Generating Station have requested that ARAC service be continued at their facilities.

- The body of experience produced through use of ARAC advisory inforination has been of great help in planning for the inclusion of future site systems, for future training, and for the design of the next-generation ARAC system.

- By the end of the orientation and planning msetings and the conclusion of the four-test series, all participants in this pilot project had learned to operate the site system and to interpret ARAC: output. This was demonstrated during the Ginna accident near Rochester, New York, when personnel from ARAC and New York State efficiently combined resourises to address the potential consequences of the accident. 
The written critiques of each series of tests provided invaluable feedback for both training and future tests, and resulted in certain formatting changes in the A RAC contours. These critiques also helped the ARAC staff develop training program meetings and tests to be used by future site system users. The divergency of backgrounds among site system users made it necessary to broaden the training and, in some cases, to individualize it so that ihe material would be understood by all users. This divergency in user backgrounds is expected to persist when future sites are incorporated into the system. Thus, the experience gained in training users at these four sites has contributed greatly to the training course now being used for Department of Defense (DOD) site personnel as ARAC expands to include DOD facilities.

The experience gained in the early installation of the site system requires that important changes be made in the future. In some cases, unnecessary delays resulted from poor communications between the ARAC and site system staffs. There were also institutional delays as a result of lengthy review procedures to a ccept budgets, as well as engineering changes at both the state offices and the utilities. To expedite the inclusion of future systems, sites personnel should be carefully informed as to budgetary needs and engineering requirements. The length of time required for institutional acceptance and procurement should be established early. Systems engineers should communicate in detail and with follow-up documentation to ensure minimum delays in delivery and installation of the site systems.

This pilot project, as well as an NRC (Nuclear Regulatory Commission) companion study of ARAC system applications for potential use by the NRC meteorological staff, has pointed out both weaknesses and strengths in the ARAC software and hardware. A number of hardware breakdowns occurred during this project due, in part, to the age of the equipment. The hardware is being updated to state of the art for the next-generation ARAC system, which, of course, should minimize downtimes. During testing, site system users reported several software errors in communications to ARAC. Some of these errors have already been corrected the remainder will be eliminated in the next-generation ARAC system.

As a result of this study, the philosophy of the next-generation ARAC system will differ greatly from that of the present system. The next-generation system will treat the ARAC center as a large computational and data source available to the user at his request, as opposed to sending large quantities of information to the user at the discretion of the ARAC staff. This philosophy will reduce the computer power required at the sites and allow the user to receive only necessary data at the time it is needed.

This pilot project has met all of the objectives established before its inception. All project participants found this utilization of ARAC service at nuclear power plants and their associated state offices to be feasible and a welcome addition to their emergency response systems. 
UCRL-53280

Distribution Category UC-11

\title{
Atmospheric Release Advisory Capability Pilot Project at Two Nuclear Power Plants and Associated State Offices of Emergency Preparedness
}

\author{
Leonard C. Rosen
}

Manuscript Date: January 1993

LAWRENCE LIVERMORE LABORATORY University of California $\bullet$ Livermore, California 94550 


\begin{abstract}
A Federal Emergency Management Agency (FEMA) sponsored project to demonstrate the feasibility of utilizing Atmospheric Release Advisory Capability (ARAC) limited service with commercial nuclear power plants and their associated state offices of emergency preparedness is discussed herein. Preliminary planning, installation and testing of the ARAC site facilities at Indian Point Nuclear Power Station, New York State, at New York State Office of Emergeney Preparedness, Albany, New York; at Rancho Seco Nuclear Generating Station, California; and at the State of California Office of Emergency Services, Sacramento, California, ure summarized. ARAC participation in the Robert $\mathrm{E}$. Ginna nuclear generating plant accident in New York on January 25, 1982, is discussed. The ARAC system is evaluated with emphasis on communications, the suite of models contained within the ARAC system, and the staff. The implications of this project in designing the next-generation ARAC system to service federal and state needs are assessed.
\end{abstract}




\section{Table of Contents}

Abstract

List of Figures

List of Tables

I. Introduction

II. The Atmospheric Release Advisory Capability . . . . . . . . . . . 1

A. Introduction . . . . . . . . . . . . . . . . . . 1

B. The Site Facility .. . . . . . . . . . . . . 3

C. ARAC Models ................... . 4

1. CPS and IPS . . . . . . . . . . . . . . . 4

MATHEW ............... 5

ADPIC ..................5

PATRIC ................ 5

III. Utilization of ARAC Services at Pilot Sites . . . . . . . . 5

A. Initial Training ................... 5

B. Installation and Operation . . . . . . . . . . . . 8

C. Testing . . . . . . . . . . . . . . . . . 10

D. Indian Point NPP/State of New York/FEMA Exercise . . . .18

E. Training Tape ............... . . . . . 22

F. Ginna Nuclear Power Plant Accident . . . . . . . . . . 24

VI. Evaluation .......................24

A. Installation ................... . . . . . . . 4

B. Operation of the ARAC System . . . . . . . . . . . .26

1. Communications .. . . . . . . . . .26

2. Models . . . . . . . . . . . . . . .26

3. Staff ................... . . . 27

C. Design Implications for the Next-Generation ARAC System . 27

VI. References . . . . . . . . . . . . . . . . . 29

Appendix A. Critique of Tests . . . . . . . . . . . . . . . . . . 30

Comment 1 . . . . . . . . . . . . . . . . . . . .30

1. Telsphone Communications with ACF . . . . . . . . . . . . . 30

2. Information Provided with Contour Plots . . . . . . . . . . .30

a. Description of Output . . . . . . . . . . . . .30

b. Graphics Output . . . . . . . . . . . .31

c. Numerical Output . . . . . . . . . . . . . . . . .

Comment 2 . . . . . . . . . . . . . . . . . . 31

1. Communicatiuns with Indian Point . . . . . . . . . . . .31

2. Communications with ACF . . . . . . . . . . . . . 32

3. Time Required for Plotting Transmitted Contours . . . . . . . .32

Comment 3 . . . . . . . . . . . . . . . . . . . . . 32

Comment 4 . . . . . . . . . . . . . . . . . . . . . . . 34

Comment 5 . . . . . . . . . . . . . . . . . . . . . . . . . . . . .

Comment 6 . . . . . . . . . . . . . . . . . . . . . 35

Comment 7 . . . . . . . . . . . . . . . . . . . . . . 36

Comment 8 . . . . . . . . . . . . . . . . . . . . 36

Comment 9 . . . . . . . . . . . . . . . . . . . . . . . . . . . . .

Comment 10 . . . . . . . . . . . . . . . . . . . . . . . . . . 


\section{List of Figures}

1. ARAC network. ....................... 2

2. ARAC central facility. . . . . . . . . . . . . . . . . . 3

3. ARAC site facility hardware. . . . . . . . . . . . . . . . 4

4. Representative contours of ARAC model calculations as $1100 \mathrm{Z}$ (based on 700Z) during the August 21, 1981, test at Indian Point. Instantaneous air concentrations of (a) I-131; (b) Xe-133; and (c) the integrated external

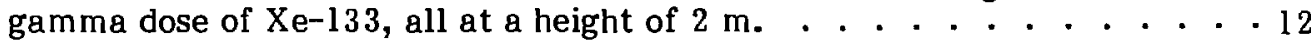

5. Representative contours of ARAC model calculations during the October 14,1981 , test at Rancho Seco. (a) Instantarieous air concentrations of Cs-137 expected at 1800Z; (b) deposition of Cs-137 at 1800Z; (c) instantaneous air concentrations of $\mathrm{Xe}-133$ at 1900Z; and (d) the integrated external gamma dose of I-13l. All contours are based on meteorology at $1700 \mathrm{Z}$ and a unit source rate. . . . . . . . . . . 13

6. Representative contours of ARAC model calculations during the September 18, 1981, test at Indian Point. (a) Instantaneous air concentrations of $\mathrm{Kr}-80$ at $2.0 \mathrm{~m}$ expected at $1350 \mathrm{Z}$; (b) integrated $\mathrm{Sr}-90$ concentrations at $2 \mathrm{~m}$ expected at 1350Z; and (c) deposition of $\mathrm{Sr}-90$ expected at $1450 \mathrm{Z}$. All contours are based on meteorology observed at $1250 Z$, a unit release rate and are calculated by employing the PATRlC

code. . . . . . . . . . . . . . . . . . . . . .

7. Representative contours of ARAC model calculations during the September 25, 1981, test at Indian Point. (a) Deposition of I-1 31 expected at $1350 \mathrm{Z}$ based on meteorulogy at 1150Z; (b) forage-cow-milk pathway infant thyroid doses for I-1 31 expected at $1350 \mathrm{Z}$ based on meteorology at at $1250 \mathrm{Z}$ due to a release rate of $1.0 \times 10^{-5} \mathrm{Ci} / \mathrm{s}$ (c) external gamma whole-body adult dose for I-13l expected at $1450 \mathrm{Z}$ based on meteorology at $1250 \mathrm{Z}$ due to a release rate of $1.0 \times 10^{-5} \mathrm{Ci} / \mathrm{s}$; and (d) integrated dose for $\mathrm{Xe}-133$ expected at $1350 \mathrm{Z}$ based on meteorology at $1150 \mathrm{Z}$ due to a unit release rate. All contours are calculated by employing the MATHEW/ADPIC codes. . . . . . . . . . . . . . . . .

8. Representative contours of ARAC model calculations during the December 4, 1981, test at Rancho Seco. (a) Integrated Xe-133 air concentrations; (b) integrated Cs-137 air concentrations; and (c) instantaneous air concentrations of I-131. All contours are at $2 \mathrm{~m}$, expected at $1800 \mathrm{Z}$ based on meteorology at $1700 \mathrm{z}$, due to a unit source rate and calculated by employing the PATRIC code. 
9. Representative contours of ARAC model calculations employing MATHEW/ADPIC codes during the January 19, 1982, test at Rancho Seco. (a) Deposition of $1-131$ for a unit source rate expected at $1815 \mathrm{Z}$ based on meteorology at 1715Z; (b) integrated Cs-137 concentrations at 2 $\mathrm{m}$ expected at $1715 \mathrm{Z}$ based on meteorology at 16157 f for a release rate of $1.0 \times 10^{-3} \mathrm{Ci} / \mathrm{s} ;$ (c) $\mathrm{I}-13 \mathrm{I}$ deposition forage-cow-milk pathways for a release rate of $1.0 \mathrm{Ci} / \mathrm{s}$ expected at $1715 \mathrm{Z}$ based on meteorology at $1615 \mathrm{Z}$; and (d) Xe-133 external gamma whole-body dose for a release rate of 1.0 $\times 10^{3} \mathrm{Ci} / \mathrm{s}$ expected at $1815 \mathrm{Z}$ based on meteorology at $1615 \mathrm{Z} . . .+. .18$

10. Representative contours of ARAC model calculations employing MATHEW/ADPIC codes during the March 3, 1982, Indian Point exercise. (a) Forage-cow-milk pathway deposited by I-13l from $1530 \mathrm{Z}$ to $2030 \mathrm{Z}$, assuming a $24 \mathrm{hr}$ grazing period (b) integrated Xe-133 concentrations at 2 $m$ expected at $2030 \mathrm{z}$ based on meteorology at $1900 \mathrm{z}$; and (c) integrated I-1 31 concentrations at $2 \mathrm{~m}$ expected at $1630 \mathrm{Z}$ based on meteorology at 1600Z. All contours are calculated using to a unit source rate. . . . . . 19

11. Representative contours of ARAC model calculations using the MATHEW/ADPIC codes displayed on the emergency preparedness training tape employing meteorclogical data for October 1,1981 . (a) In tegrated I- 131 concentrations at $2 \mathrm{~m}$ at $1900 \mathrm{Z}$ based on meteorology at $1800 \mathrm{Z}$; integrated $\mathrm{Xe}-133$ concentrations at $2 \mathrm{~m}$ at $1900 \mathrm{Z}$ based on meteorology at 1800Z; instantaneous air concentrations of Xe-133 at $2 \mathrm{~m}$ at $2000 \mathrm{Z}$ based on meteorology at 1900Z; and (d) deposition of Sr-90 at 1900Z based on meteorology at 1800Z. All contourc are calculated using a unit source rate. . . . . . . . . . . . . . . . . . . . . 21

12. Represe.،tative contours of ARAC model calculations employing MATHEW/ADPIC codes transmitted during the January 25, 1982, Robert E. Ginna nuclear power plant accident. (a) Instantaneous air concentrations of Xe-133 at $2 \mathrm{~m}$ at $1500 \mathrm{Z}$ based on meteorology at 1400Z; (b) instantaneous air concentration of Xe-133 at $2 \mathrm{~m}$ at $1600 \mathrm{Z}$ based on meteorology at $1400 \%$ (c) integrated Xe-133 concentrations at $2 \mathrm{~m}$ at $1500 \mathrm{Z}$ based on meteorology at 1400Z; and (d) integrated Xe-133 concentrations at $2 \mathrm{~m}$ at $1600 \mathrm{Z}$ based on meteorology at $1400 \mathrm{Z}$. All calculations are based on a unit release rate. . . . . . . . . . . . 23 


\section{List of Tables}

1. Agenda for ARAC orientation/planning meeting, September 16-17, 1980. • . 7

2. Agenda for ARAC orientation meeting, Friday, October 2, 1981. . . . . 8

3. NPP/State/ARAC Training Program. . . . . . . . . . . . . . . 9

4. Training tapes. . . . . . . . . . . . . . . . . . . 20 


\section{Atmospheric Release Advisory Capability Pilot Project At Two Nuclear Power Plants and Associated State Offices of Emergency Preparedness}

\section{Introduction}

The Federal Emergency Management Agency (FEMA) has supported a pilot project with the Lawrence Livermore $\mathrm{National}$ Laboratory (LLNL) to demonstrate the feasibility of utilizing Atmospheric Release Advisory Capability (ARAC) limited service with commercial nuclear power plants and to provide a basis for considering more extensive applications of the ARAC system on a national scale. The objectives of the project were:

1. To install and demonstrate the use of ARAC site facility terminals at Indian Point Nuclear Power Station, New York State; at the New York State Office of Emergency Preparedness, Albany; at Rancho Seco Nuclear Generating Station, California; and at the State of California, Office of Emergenay Services (OES), Sacramento.

2. To train site system personnel in the use of ARAC advisory information relevant to emergency response in case of a nuclear accident.

3. To respond to these sites in case of an actual nuclear accicient.

4. To provide a tape of isopleths for use in emergency preparedness exercises.

The background and description of the ARAC system is contained in section II of this report. The use of ARAC services at the pilot sites is described in section III under the subheadings "Initial Training," Installation and Operation," "Testing," "Indian Point NPP/State of New York/FEMA Exercise," "Training Tape," and "Ginna Nuclear Power Plant Accident." Section IV is devoted to an evaluation of the ARAC system and includes discussions on installation, communications, models, staff, and design implications for the design of the next-generation ARAC system.

\section{The Atmospheric Release Advisory Capability}

\section{A. Introduction}

The ARAC project was initiated by the Atomic Energy Commission (now the Department of Energy, DOE) to develop a computer-based capability that could produce rapid projections (advisories) of the transport, diffusion, and deposition of radioactive material released into the atmosphere. The feasibility of the concept was demonstrated in 1975, after which time the central facility was established at LLNL and computer data processing equipment was installed at selected DOE sites l

The ARAC system makes available to users predictive data from proven and tested numerical models. ${ }^{2-6}$ Geographical scales for ARAC assessments vary from regional (up to $100 \mathrm{~km}$ ) to global (thousands of $\mathrm{km}$ ), depending on the release conditions. Component parts of the system are shown in Fig. 1. At present, ARAC services are available to four DOE sites, to the Federal Aviation Administration (FAA), to DOE emergency response operations (e.g., the Nuclear Emergency Search Team), to the NRC's Incident Response Center, to two nuclear puwer plants (Indian 


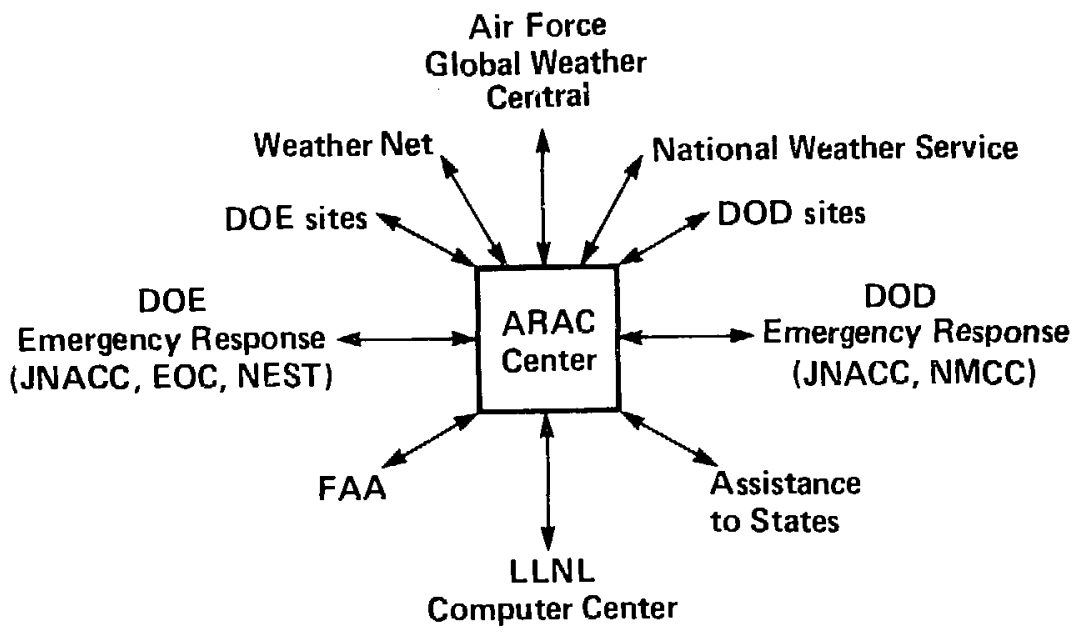

Figure 1. ARAC network.

Point and Rancho Seco), to two state offices for emergency services (New York and California), and to three DOD sites.

The ARAC center (Fig. 2) is the focal point for data acquisition, data processing, communications, and assessments through the use of interconnected minicomputers. One or more of the several CDC 7600 computers at the LLNL computer center is used to calculate regional and global atmospheric transport and diffusion estimates. In an atmospheric release emergency, the ARAC staff can obtain exclusive use of a CDC 7600 computer minutes after the computer center is notified.

Meteorological data from Air Force Global Weather Central (AFGWC) at Offutt Air Force Base, Bellevue, Nebraska, are available to the ARAC center through a high-speed data link. The ARAC center can receive, analyze, display, and store meteorological data from worldwide data sources. Selected observational and forecast data are also received on a routine scheduled basis. In an emergency, ARAC can request supplemental data from either the AFGWC computer system or the master data base at Carswell Air Force Base, Fort Worth, Texas. The AFGWC gives ARAC high priority under emergency conditions, thereby speeding the response. Presently, supplemental and backup weather data are received from the National Weather Service (NWS) through normal teletype and facsimile channels. In the future, consideration will be given to including updated NWS Automated Forecast Office Service systems in the ARAC network. 


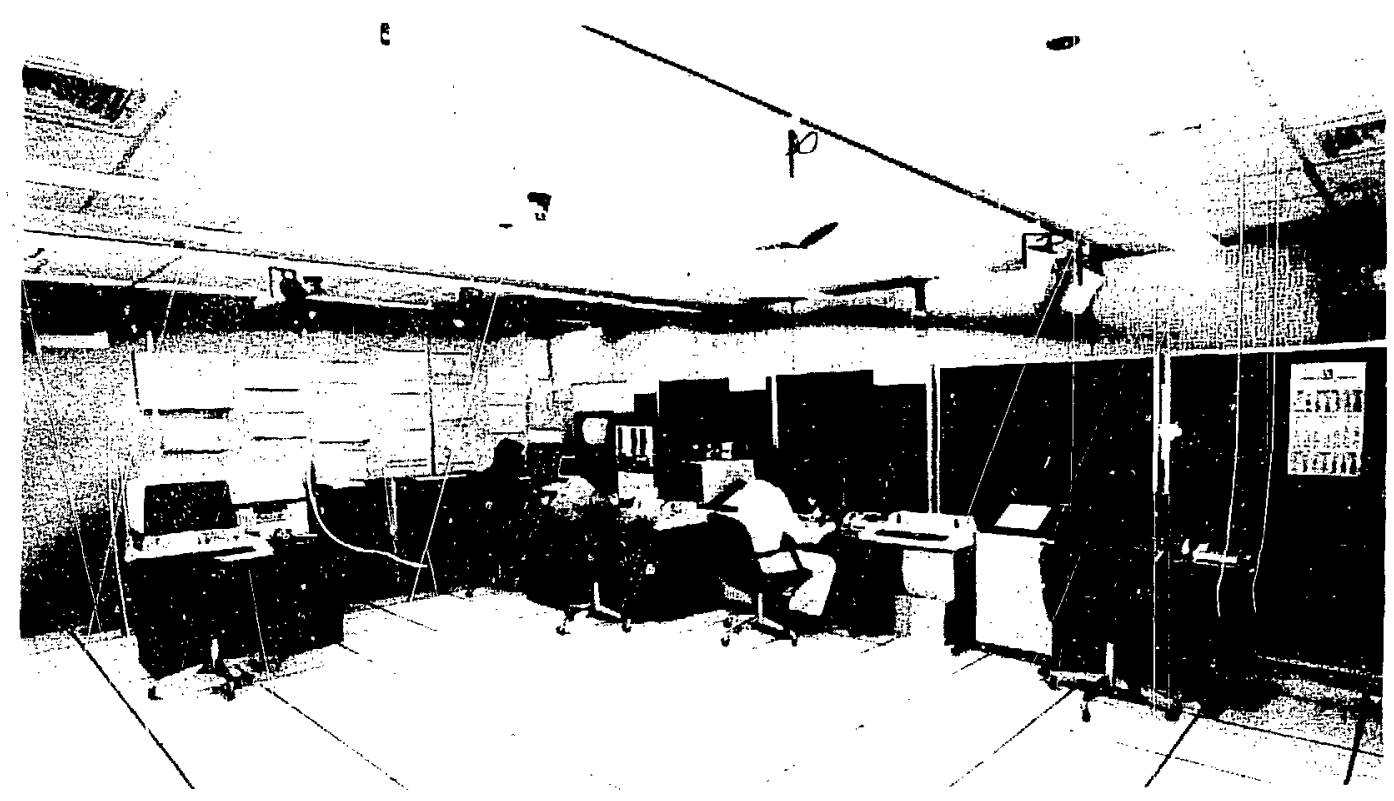

Figure 2. ARAC central facility.

\section{B. The Site Facility}

Each ARAC-serviced site has a minicomputer or si - terminal that furnishes local data-acquisition, assessment, and communications capabilities. Its specific functions include:

1. Multiplexing the environmental sensors.

2. Calculating and displaying Gaussian diffusion estimates for close-in distances (out to approximately $5 \mathrm{~km}$ ), using the latest local meteorological data. facility.

3. Transmitiing local environmental monitor measurements to the central

4. Receiving and displaying regional calculations from the central facility.

The site terminal hardware is illustrated in Fig. 3. The central processor is a DEC PDP-l l with a maximum memory of $28 \mathrm{~K}$ words. The terminal uses a DECTAPE for program and data storage. Two graphics output devices are used for displaying maps, overlays, and similar information. The first graphics output device, a 17-in. CRT monitor, uses a $28 \mathrm{~K}$ memory to refresh the graphics display. The second device an ll-in. printer/plotter, is referred to as the hard-copy device because the display is documented on paper. To communicate with the computer, the operator uses the keyboard and the light pen. By typing appropriate responses on the keyboard, the operator can provide input data and communicate with the site terminal and, with the light pen, can point to a command for an appropriate system response. A watch-dog timer and bootstrap function are provided to start the site terminal and to restart when the system is stopped by unexplained or undetected errors. There are also data lines to collect data from the meteorological towers and 




Figure 3. ARAC site facility hardware.

to communicate them to the ACF. Two functions of the site terminal minicomputer are to calculate Gaussian diffusion estimate every $15 \mathrm{~min}$, based on average data collected from the meteorological towers, and to provide interactive responses to the operator's data input.

\section{ARAC Models}

The ARAC system uses a suite of numerical models appropriate to a variety of atmospheric release incidents. The following ARAC models are pertinent to the use of the ARAC service for the release of radionuclides from nuclear power plants.

\section{CPS and IPS}

These Gaussian continuous- and instantaneous-point-source diffusion models are part of the ARAC site system menu and are used on-site for first-response calculations in the event of an exercise or accidental release. A unit release rate (CPS) or release (IPS) is assumed.

Two modes of operation are available. The first, more commonly used mode is automatically updated on the screen every $15 \mathrm{~min}$, and provides concentration contours overlaid on a geographical map. These contours are calculated from a preselected input file that includes the height and location of the tower from which the 15-min average wind direction and speed are desired, the map size (detailed or regular), and whether the release is a plume or a puff. The site system determines the atmospheric stability category by calculating the standard deviation (related to stability) over the $15-$ min period.

The second mode allows the user to change the preselected input file. Items that may be changed are the sampler height, the location and height of the release, 
the half-life, the stability category, and the wind direction and speed.

MATHEW2,3

This flexible, three-dimensional model provides nondivergent wind fields for use in the ADPIC model and various studies. It adjusts interpolated wind-field data, subject to the constraints of mass continuity and explicitly introduced topography. Also, it is available for other studies, such as assessing windpower sites and topographic influences.

\section{A DPIC4.5}

This three-dimensional, particle-diffusion model calculates the transport and diffusion of a puff or plume in a time-varying atmospheric boundary layer. It is based on the particle-in-cell (PIC) concept, with the hydrodynamical aspects of the conventicnal PIC deleted. This computer model has been used to simulate particulate and gaseous concentrations from one or more sources at distances beyond $100 \mathrm{~km}$, the general deposition of particles with given size distributions, and rainout. In addition, ADPIC calculations have been compared against measurements for four field-diffusion experiments. The MATHEW/ADPIC transport and diffusion models are continually being modified and verified against field tracer studies to provide ARAC users with useful products in a timely marner.

\section{PATRIC6}

The particle-trajectory-in-cell (PATRIC) modei is a transport and diffusion model designed to calculate the three-dimensional distribution of atmospheric pollutants in a given flow field varying with space and time. The model can compute instantaneous or time-integrated air concentrations and deposition for a variety of instantaneous or continuous sources, including inert and radioactive materials. The PATRIC model was developed to fill the need for a fast-running annual assessment tool that can serve as a basis for dose-to-man calculations. It is generally related to ADPIC in that it is a particle-in-cell model but, because the model includes no topography or vertical wind velocities and because its diffusion calculation is independent of a grid, PATRIC can run about a thousand times faster than real time.

\section{Utilization of ARAC Services at Pilot Sites}

The sequence of events leading to and including the implementation of ARAC service at Indian Point NPP, the $\mathrm{New}$ York State Office of Emergency Preparedness, Rancho Seco NPP and the California OES is discussed within this section under Initial Training, Installation and Operation, Testing, and Training Tape. It may be noted that several milestones were not demonstrated simultaneously for the California and $\mathrm{New}$ York sites because of differences in their time of entry into the project. The New York sites joined the pilot project in April 1980, whereas the California sites began in November 1980.

\section{A. Initial Training}

The first step in establishing ARAC service at the pilot sites was to organize meetings at LLNL with personnel from the prospective sites. On September 16 and 17, 1980, an ARAC orientation and planning meeting was held at LLNL. This meeting included representatives from Con-Edison, the Power Authority of New York (PASNY), the New York State Health Department, and FEMA. 
The meeting had two purposes: (1) to bring together those who would be involved in the operation, interpretation, and management of the ARAC site facilities at Indian Point NPP and the State of New York Emorgency Response Center so that they might learn more about the ARAC system; and (2) to plan goals and operational procedures for ARAC implementation during the coming year. The meeting agenda is given ir, Table 1 .

California pilot project representatives included personnel from the Rancho Seco NPP (Sacramento Municipal Utilities District), the State of California OES, and the State of California Department of Health. These personnel had, since 1979, moen in communication with the ARAC staff, through an initial ARAC feasibility scudy performed for the NRC.8 Further, the Rancho Seco and State of California representatives had become familiar with the workings of the ARAC system through briefings and denuonstrations. Therefore, only a shortened ARAC orientation meeting was required to review details and plan for the forthcoming testing. The A RAC orientation meeting for the California pilot project personnel was held October 2, 1981, after installation of the equipment and just prior to testing. The agenda for this meeting is shown in Table 2.

\section{B. Installation and Operation}

To expedite and facilitate installation and operation of ARAC site system facilities, users receive documentation 9,10 and instructions before the system is delivered. By this time, the users will have already instituted a service contract with the equipment manufacturer and have the requisite data communications equipment The utility organizations that operate the nuclear power stations are required to provide the electronic interface between the site systems and the site meteorological towers.

The Indian Point NPP and site system were shipped by LLNL on August 12 s 1980. The equipment manufacturer, DEC, performed the initial setup and installation on September 4, 1980. On this same date, the meteorological tower hookup was completed. The New York State site system was shipped by LLNL on October 7, 1980, and DEC performed the initial installation and setup on November 3 , 1980. However, phone lines had not been installed at that time. After a considerable delay, despite much communication between LLNL, the State of New York, and the telephone company, it was discovered that the ordering paperwork had been lost in transition when the phone coordinator in the telephone company retired. The lines were finally installed on January 16, 1981. An ARAC staff member travelled to the site facility system at Indian Point NPP and Albany, New York, to complete the installation, deliver new site maps, and verify their continued operation in February 1981.

The ARAC site facility system was delivered to SMUD's (Sacramento Municipal Utilities District) Rancho Seco NPP on February 17, 1981. However, the meteorological interface and telephone links were not delivered uritil April 19 $\{1$, at which time they were installed. The delivery of an ARAC site facility system to the State of California OES was delayed somewhat by the necessity of California State clearance on processing form 424. After State clearance had been received and the equipment had been delivered to the CES on May 4, 1981, was discovered that the area in which the ARAC equipment was to be used required both additional power and air conditioning. The power wiring was completed in June 1981, and the air 
TABLE 1. Agenda for ARAC orientation/planning meeting, September 16-17, 1980.

Tuesday, September 16

$\begin{array}{cll}\text { 8:00-8:30 } & \text { Check in at Badge Office } & \\ \text { 9:00 } & \text { Introduction } & \text { Len Rosen } \\ \text { 9:15 } & \text { Opening Remarks } & \text { Joe Knox } \\ 9: 45 & \text { General Overview } & \text { Len Rosen } \\ 10: 15 & \text { Coffee Break } & \\ 10: 30 & \text { ARAC Services } & \text { Tom Sullivan } \\ \text { 11:30 } & \text { Lunch } & \\ \text { 1:00 } & \text { ARAC Network } & \text { Brian Lawver } \\ 2: 00 & \text { Coffee Break } & \\ 2: 15 & \text { Demonstration - Tour in ARAC Center } & \\ 3: 15 & \text { Discussion } & \text { Len Rosen } \\ & & \end{array}$

Wednesday, September 17

\begin{tabular}{rll} 
8:30 & Remarks & Len Rosen \\
$9: 00$ & Con-Edison/PASNY & Lešter Cohen \\
$9: 30$ & State of New York & John Matuszek \\
10:00 & NRC Demonstration of Site System at & \\
& Headquarters & Earl Markee \\
$10: 30$ & NRC Field Experiments & Bob Abby \\
$11: 00$ & FEMA & Bob Jaske \\
$11: 30$ & Lunch & \\
$1: 00$ & Remarks & Len Rosen \\
1:15 & Planning Session & All Participants \\
$3: 30$ & Action Paper and Wrap-up & All Participants \\
\hline
\end{tabular}


TABLE 2. Agenda for ARAC orientation meeting, Friday, October 2, 1981.

9:30 In troduction and General Overview

10:00 ARAC Network

10:45 Coffee Break

1 1:00 Demonstration and Tour of ARAC Center

12:00 Discussion
Len Rosen

Brian Lawver

Len Rosen and

all participants

conditioning was installed on July 7, 1981. Telephone communication links had not been received at the time the wiring and air conditioning were completed. The modems were ordered on June 12,1981 , and installed by the telephone company on August 24, 1981. However, the meteorological tower interface from the tower at $\mathrm{R}$ ancho Seco to the California OES was connected improperly; thus meteorological data could be received by the site facility system at Rancho Seco, but not by the OES. The need to formally plan the changes, get approval to spend the necessary funds, and rewire delayed the transmission of this data to the State of California until Novembèr 1981. Meanwhile, an ARAC staff system engineer visited both sites on numerous occasions to ensure proper operation of the hardware, software, and communications.

\section{Testing}

A program of on-the-job systems training was developed for participants in the pilot project. The training consisted of a series of four tests (Fig. 6) for each site. The tests were constructed so that the expertise and familiarity of the system user increased in complexity with each test. The exercises were arranged so that personnel at the utility operating the NPP and the State Emergency Response Office associated with the power plant would be proficient enough at the conclusion of the testing program to use the system competently in the event of an actual nuclear accident.

The first two tests were performed individually between each site user and the ACF. The first test constituted initial hands-on testing of site personnel. Its purpose was to familiarize site system users with the operation of site/ACF communications and with the ARAC-generated contour package. The objective of the second test was twofold: mode.

1. To exercise the NPP/State/ACF emergency response in a nonintensive

2. To give site personnel and ARAC teams a near realtime learning experience working with a previously thought-out emergency scenario and "canned" meteorological data.

The details of the procedure are discussed in Table 3 . The first two tests for the State of New York were performed August 14 and 21, 1981, respectively. The first 
TABLE 3. NPP/State/ARAC Trilining Program.

Exercise 1. Communications/Operations Training

Objective: To familiarize site system operators wi:h the operation of site/ARAC central facility (ACF) communications and with the ARAC-generated contour package.

Procedures: At a mutually agreed on time and date, the ACF will transmit to the site system a set of ARAC model calculations. 1 This training will be accomplished over a period of two days, nne day for each of the above mentioned agencies. The time devoted to each day's training should not exceed three hours duration. A series of system manipulations are planned. They will include:

a. Emergency communications

b. Nonemergency communications

c. Site system Gaussian calculations

d. Review of site meteorological data

e. Sizing of regional and trajectory maps

f. Viewing of transmitted contours

g. Printing of CRT information.

Expected

outcome:

Familiarization with ACF/site communications and ARACtransmitted contours. A written critique is requested from all participants.

\section{Exercise 2. Level A Emergency Exercise}

Objective: (1) To exercise the NPP/State/ACF emergency response in a nonintensive mode.

(2) To give site personnel and ARAC teams a learning experience working near realtime with a previously thoughtout emergency scenat to and "cannej" data.

Procedures: At a mutually agreed on time and data, the ACF will transmit to the NPP ARAC site system and the State ARAC site system a set of A RAC calculations. The timing and scheduling will be as in exercise 1 , above. The aspects of the scenario for this emergency exercise will be mutually agreed on, such as time of day, stabilitj, mixing depth, nuclides involved, source-term data, release point, and output desired. The ARAC code "PATRIC" will be used for these calculations. Real meteorological data will be used; however, the calculations will not be made in realtime. They will be prepared before the exercise day, and the contours will be transmitted during the training exercise.

Expected

Outcome:

An understanding of the mechanics of a site accident declaration and ARAC response. A written critique is requested from all participants.

${ }^{1}$ All ARAC model calculations will be normalized $(\chi / Q)$. In exercise 4 , however, dose calculations will be made on request, using utility-supplied dose-conversion f actors and source-term information. 
Exercise 3. Level B Emergency Exercise

Objective: To utilize knowledge gained via the Level A emergency exercise and subsequent critique, to streamline procedures in near realtime, and to increase the experience level of both site and ARAC operational personnel.

Procedures: The timing and scheduling for this exercise will be decided mutually by all participants. This exercise will involve all participants on the same day and will exercise the communications procedures for transmitting data to the State Office first and to the NPP site second and, in general, parallel communications between the ACF and both site systems. As in exercise 2, the PATRIC code will be used for these calculations. The calculations will be run on a predetermined scenario as in exercise 2, but will be run in realtime, using realtime meteorology, however, calculations will be prepared and transmitted in a nonintensive mode. At least four hours should be set aside for this exercise.

Expected

outcome:

Increased awareness of accident definition and ARAC response procedures. A written critique is requested from all participants.

Exercise 4. Major Systems Exercise

Objective: To test the complete ARAC system, via a preconceived scenario, on a preselected day.

Procedures: As in exercise 3, this exercise will include parallel communications to the utility and to the State office. The scenario is to be conceived by $\mathrm{ARAC}$ and the State Office as a reasonably likely accident scenario. The data are to be agreed on by the site and the ACF, with enough lead time given to ensure cooperation with the LLNL computations center. The ARAC codes MATHEW and ADPIC will be used to generate a mass-consistent wind field and resulting concentrations. Because of the manpower requirements on such a major systems exercise, the length of the exercise, i.e., the number of hours running the volume of data transmitted (and its format) must be agreed on in advance. This exercise will be accomplished in realtime, using real-time meteorology. The start time of this exercise will be predetermined and mutually agreed on.

Expected outcome:

Experience in handling ARAC site emergencies. A written critique is requested from all participants. 
test for Indian Point N PP :as delayed until September 1, 1981, because of hardware problems. The second test for Indian Point was completed September 10, 1981 . During the second test, ARAC calculations using the numerical code PATRIC were sent to the sites. Representative contours are shown in Figs. 4(a) to 4(c). These contours represent, at a height of $2 \mathrm{~m}$, the instantaneous air concentrations of $\mathrm{I}-1 \mathrm{l}$, the instantaneous air concentrations of $\mathrm{Xe}-133$ at two meters and the integrated external gamma dose of Xe-133, respectively. All contours are given at $1100 \mathrm{Z}$, based on meteorology at $0700 \mathrm{z}$ and a unit source rate. These contours were included in those sent to both $\mathrm{New}$ York site facilities during exercise 2.

The first tests exercises were performed between Rancho Seco NPP and the ACF on October 8 and 14, 1981. The first test for the State of California OES was executed on October 14, 1981. Communications hardware problems developed during the second test on October 16, 1981, so the test had to be repeated on November 3, 1981. To ensure proper communications and expedite required hardware repair, an ARAC staff engineer was present at the OES during the second test. Representative contours transmitted by ARAC to the sites during test 2 are shown in Figs. 5(a) to 5(d). These contours, at $2 \mathrm{~m}$, represent the instantaneous air concentration of $\mathrm{Cs}^{-137}$ expected at $1800 \mathrm{Z}$, the deposition of $\mathrm{Cs}^{-137}$ at $1800 \mathrm{Z}$, the instantaneous air concentration of Xe-133 at 1960Z, and the integrated external gamma dose of $1-131$ at $1800 \mathrm{Z}$. All contours shown are based on meteoralogy at $1700 \mathrm{Z}$ and a unit source rate.

The last two tests in the four-part series are designed to be performed jointly by the utility, the associated state of fice, and the ACF. The thiir test is designed so that personnel at the nuclear power plant and the State Emergency Preparedness Office can communicate with ARAC as they would in case of an actual ruclear accident. The successful completion of exercises 1 and 2 ensures that these institutions are familiar with the operation of site facility hardware, understand the communications, and can interpret the contours transmitted to them by the ACF. As in test 2, the third exercise again employs the PATRIC code and a preestablished accident scenario, but uses existing meteorology at the time of the test. The test proceeds nonintensively, with extra time allotted for training and communications. The fourth and final test simulates the interactive responses of the utility, state, and APAC in the event of a nuclear accident. The scenario, although preconceived by all parties involved in the exercise, is conducted in a reattime sequence, employing real-time meteorology and the MATHEW and ADPIC numerical codes.

Exercises 3 and 4 were conducted jointly between the Indian Point NPP, the State of New York Office of Emergency Preparedness, and ARAC on September 18 and 25, 1981. Figures 6(a) through 6(c) are representative contours transmitted by the ACF on September 18, 1981 to both the State of New York and Indian Point N PP , during exercise 3. These contours are for the instantaneous air concentration of $\mathrm{Kr}-88$ expected at $1350 \mathrm{Z}$, the integrated $\mathrm{Sr}-90$ expected at $1350 \mathrm{Z}$, and the $\mathrm{Sr}-90$ deposition expected at $1450 Z$, respectively. All are based on meteorology observed at $1250 \mathrm{Z}$, and a unit release rate and are calculated by employing the PATRIC code. Some of the contours transmitted to both the State of New York Office of Emergency Preparedness and Indian Point NPP during exercise 4 on September 25, 1981 , are shown in Figs. $7(a)$ through $7(d)$. These calculations utilized the MATHEW/ADPIC numerical codes. Figure 7(a) represents contours for the I-13] 

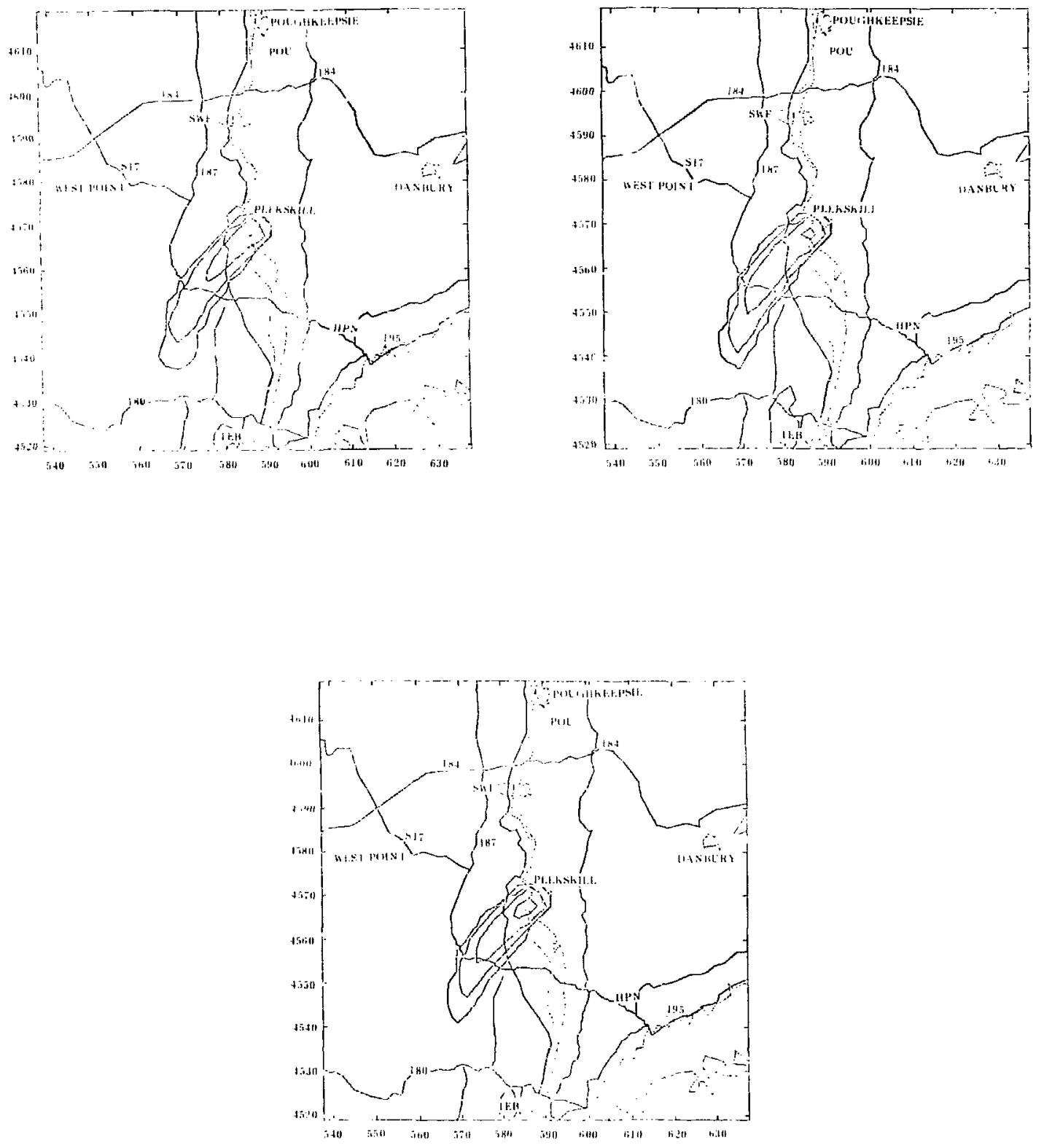

Figure 4. Representative contours of ARAC model calculations as $1100 \mathrm{Z}$ (based on $700 \mathrm{Z}$ ) during the August 21, 1981, test at Indian Point. Instantaneous air concentrations of (a) $1-131$; (b) Xe-133; and (c) the integrated external gamma dose of $\mathrm{Xe}-133$, all at a height of $2 \mathrm{~m}$. 

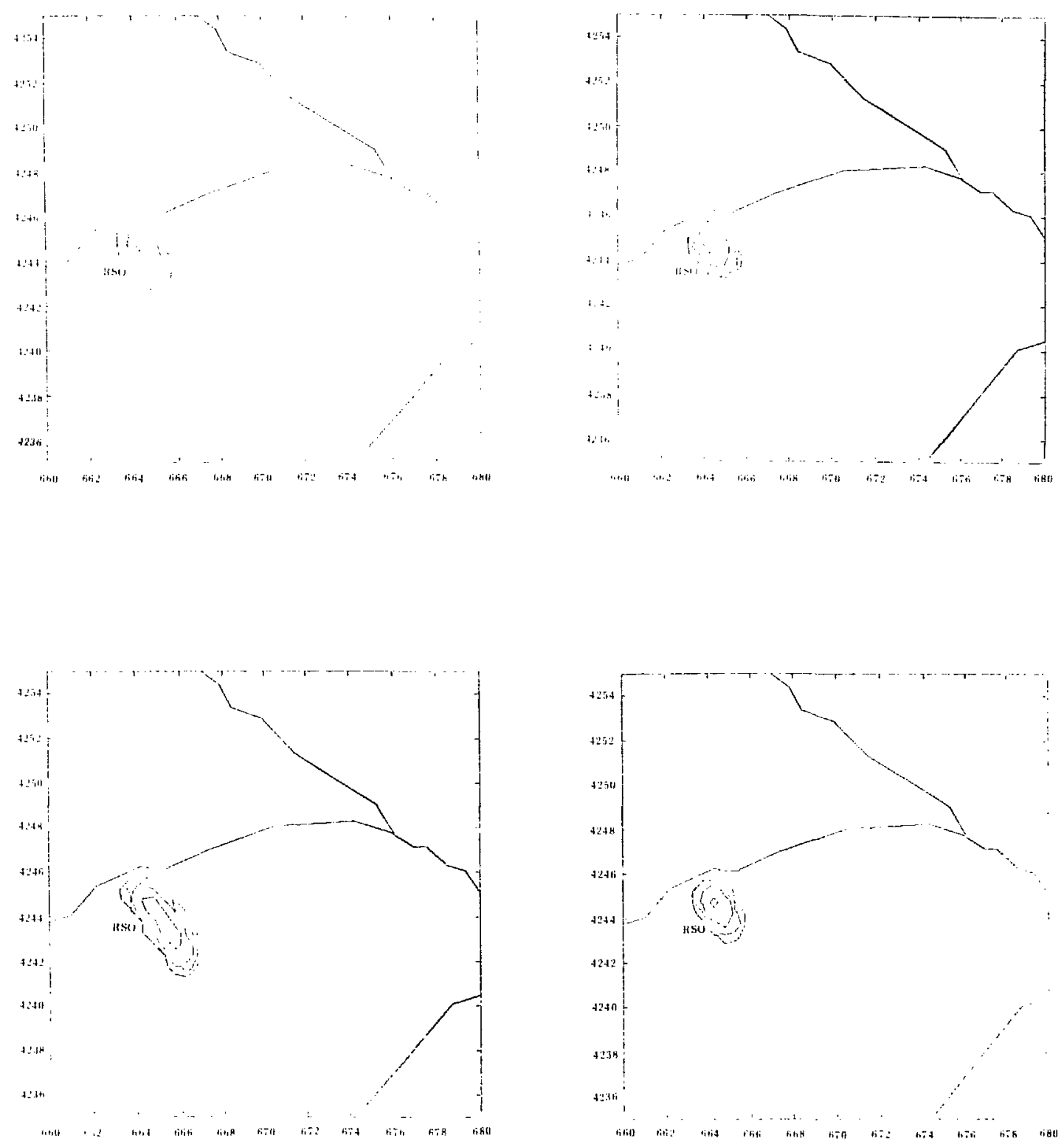

Figure 5. Representative contours of ARAC model calculations during the October 14,1981 , test at Rancho Seco. (a) Instantaneous air concentrations of Cs-137 expected at 1800Z; (b) deposition of Cs-137 at 1800Z; (c) instantaneous air concentrations of Xe-133 at 1900Z; and (d) the integrated external gamma dose of I-131. All contours are based on meteorology at $1700 \mathrm{Z}$ and a unit source rate. 

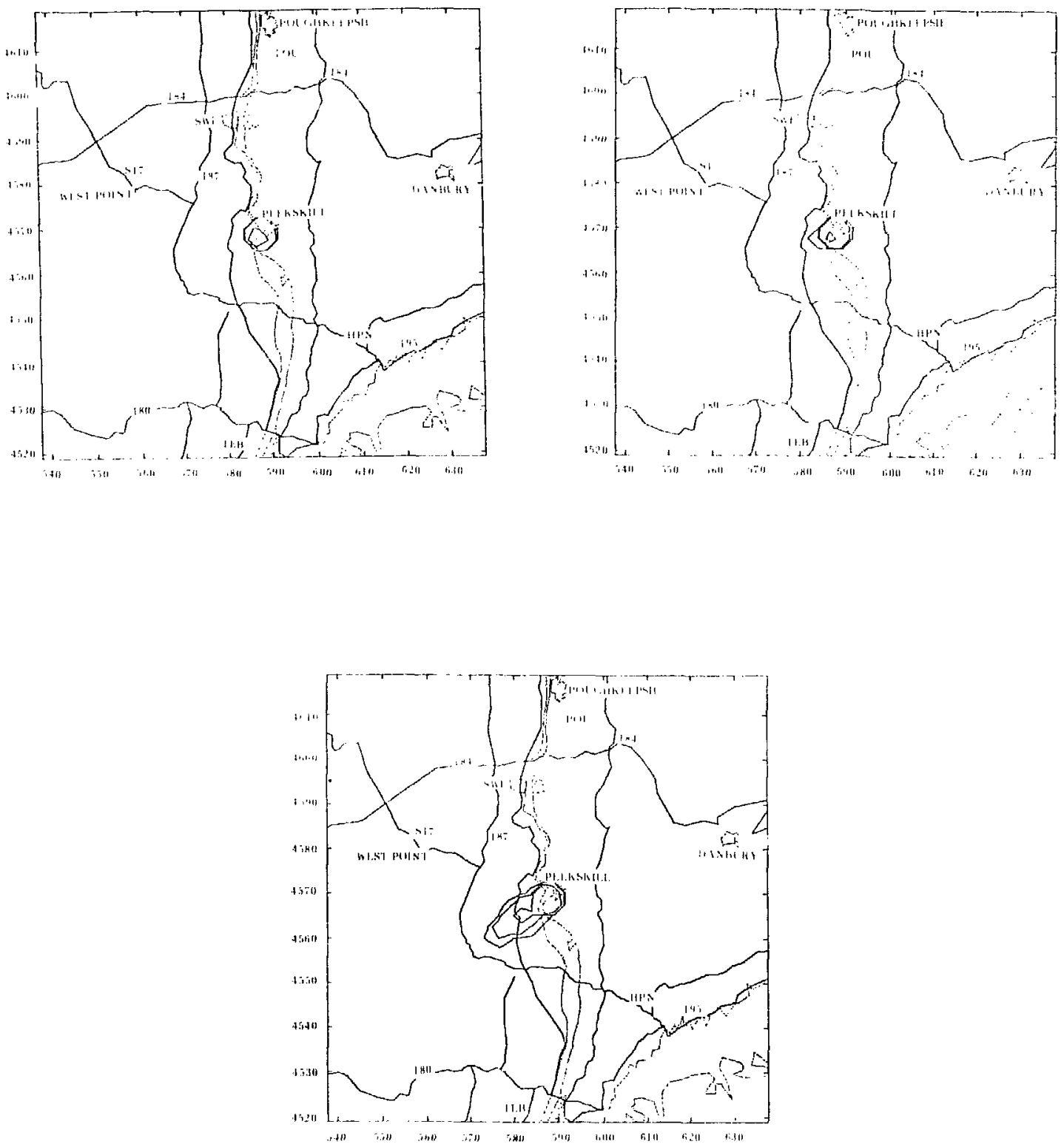

Figure 6. Representative contours of ARAC model calculation during the


$\mathrm{Kr}-80$ at $2.0 \mathrm{~m}$ expected at 1350Z; (b) integrated $\mathrm{Sr}-90$ concentrations at $2 \mathrm{~m}$ expected at 1350Z; and (c) deposition of $\mathrm{Sr}-90$ expected at $1450 \mathrm{Z}$. All contours are based on meteorology observed at $1250 \mathrm{Z}$, a unit release rate and are calculated by employing the PATRIC code. 

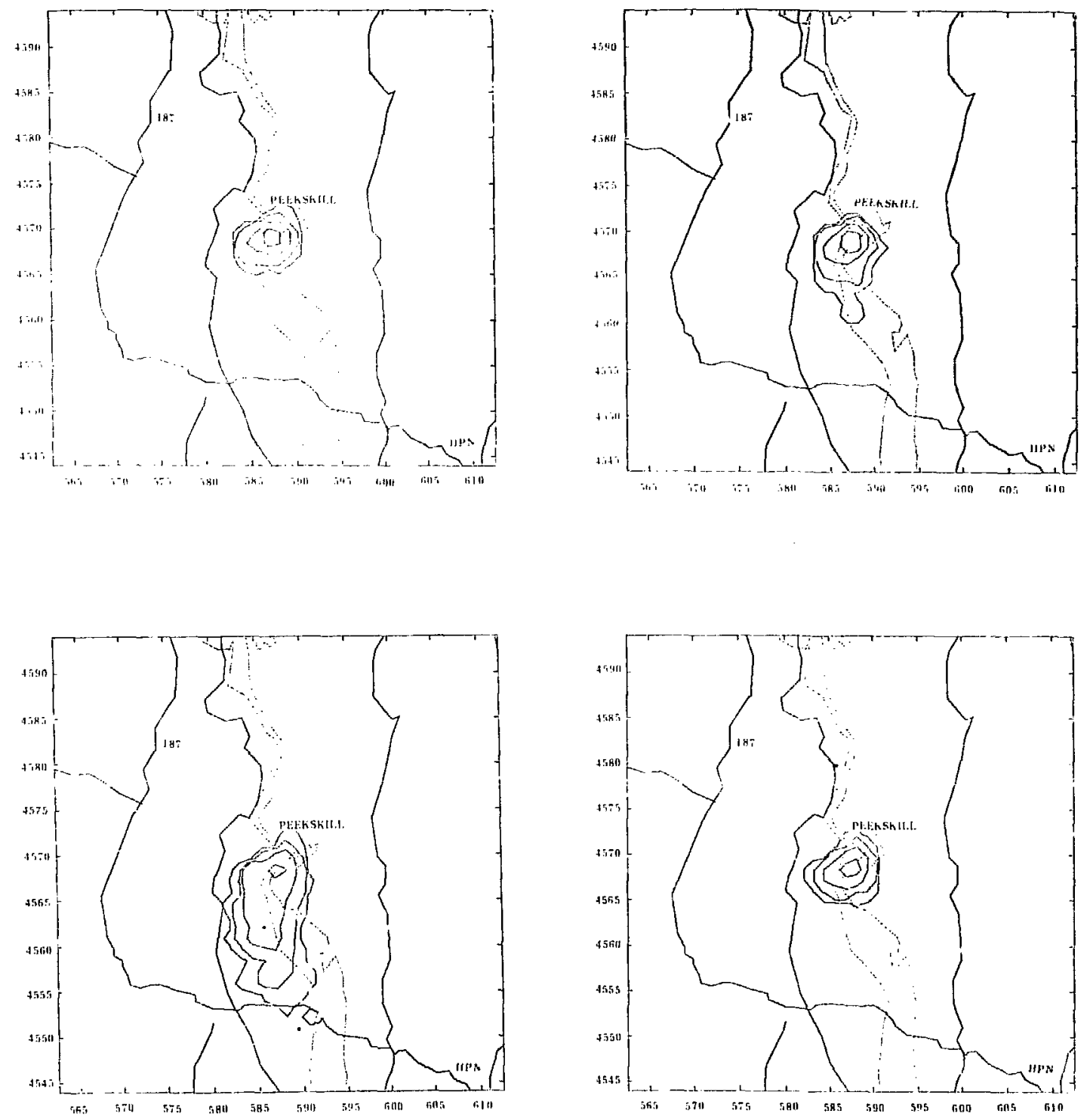

Figure 7. Representative contours of ARAC model calculation during the September 25, 1981, test at Indian Point. (a) Deposition of I-131 expected at $1350 Z$ based on meteorology at 1150Z; (b) forage-cow-milk pathway infant thyroid coses for I-131 expected at $1350 \mathrm{Z}$ based on meteorology at at $1250 \mathrm{Z}$ due to a release rate of $1.0 \times 10^{-5} \mathrm{Ci} / \mathrm{s}$; (c) external gamma whole-body adult dose for I-131 expected at $1450 \mathrm{Z}$ based on meteorology at $1250 \mathrm{Z}$ due to a release rate of $1.0 \times 10^{-5} \mathrm{Ci} / \mathrm{s}$; and (d) integrated dose for $\mathrm{Xe}-133$ expected at $1350 \mathrm{Z}$ based on meteorology at $1150 \mathrm{Z}$ due to a unit release rate. All contours are calculated by employing the MATHEW/ADPIC codes. 
expected at $1350 \mathrm{Z}$, based on meteorology observed at $1150 \mathrm{Z}$ and a unit release rate. Figures $7(\mathrm{~b})$ and $7(\mathrm{c})$ represent, respectively, the forage-cow-milk pathway infant thyroid doses for I-131 and the external gamma whole-body adult dose for I-131, based on a release rate of $1.0 \times 10^{-5} \mathrm{Ci} / \mathrm{s}$. Figure $7(\mathrm{~d})$ represents, respectively, the integrated dose for $\mathrm{Xe}-133$, based on a unit release rate.

The third exercise, the first joint test between the Rancho Seco NPP and the California State Office of Emergency Preparedness, was performed on November 25,1981 , and then repeated, because of communications and data collection problems, on December 4, 1981. Representative contours transmitted by ARAC to both the Rancho Seco NPP and the State of California are shown in Figs. 8(a) through $8(\mathrm{c})$ and were calculated by the PATRIC numerical code, using a unit source rate. The figures are, respectively the integrated $\mathrm{Xe}-133$, integrated $\mathrm{Cs}-137$, and instantaneous $\mathrm{I}-13 \mathrm{l}$, all at $2 \mathrm{~m}$, expected at $1800 \mathrm{Z}$ on the basis of observed meteorology at $1700 \mathrm{z}$.

The fourth and final regularly scheduled exercise for training California site system users took place January 19, 1982. Figures 9(a) through 9(d) are representative of the contours transmitted by $A C F$ to both California pilot sites; they were calculated by the MATHEW/ADPIC numerical codes. Figure 9 shows contours for I-131 deposition for a unit source rate expected at 1815Z, based on meteorology observed at 1715Z. Figure 9(b) gives the integrated Cs-137 at $2 \mathrm{~m}$ expected at $1715 \mathrm{Z}$, based on meteorology observed at $1615 \mathrm{Z}$ for a Cs-137 release rate of $1.0 \times 10^{-3} \mathrm{Ci} / \mathrm{s}$. Figures $9(\mathrm{c})$ and $9(\mathrm{~d})$, show respectively, the $131-\mathrm{I}$ deposition forage-cow-milk pathways for a release rate of $1.0 \mathrm{Ci} / \mathrm{s}$ and the $\mathrm{Xe}-133$ external gamma whole-body dose contours for a release rate of $1.0 \times 10^{3} \mathrm{Ci} / \mathrm{s}$. Figures 9 (c) and $9(\mathrm{~d})$ give the isopleths expected at $1715 \mathrm{Z}$ and $1815 \mathrm{Z}$ respectively, both based on observed meteorology at $1615 \mathrm{Z}$.

\section{Indian Point NPP/State of New York/FEMA Exercise}

As a part of the continuing cooperation between ARAC and its pilot sites, the ACF participated in a joint exercise planned by FEMA for a radiological release at the Indian Point unit no. 3 on March 3, 1982. The exercise proceeded in execution similar to test 4 in that real-time meteorology was employed and contours were calculated utilizing the MATHEW/ADPIC numerical codes. However, transmission of the contours was done by use of telecopiers rather than through the site system due to a number of past hardware and communication problems present in the system and to simplify communications during the exercise. The release began at $1536 \mathrm{Z}$ and terminated at $1930 \mathrm{Z}$. Contours were sent by ACF to the New York State Office of Emergency Preparedness until 2300Z. Figures 10(a) through 10(c) are representative calculations performed using ADPIC/MATHEW numerical codes. Since the source rate was unclear and undetermined except approximately throughout the exercise, all calculations were performed using a normalized source rate. Figure $10(a)$ gives the forage-cow-milk pathway dose contour deposited by I-1 31 from $1530 \mathrm{Z}$ to $2030 \mathrm{Z}$, assuming a $24 \mathrm{hr}$ grazing period. Figures 10 (b) through $10(\mathrm{c})$ shows Xe-133 integrated at $2 \mathrm{~m}$ expected at $2030 \mathrm{Z}$ based on meteorology at 1900Z. Figure $10(\mathrm{c})$ displays integrated $\mathrm{I}-131$ at $2 \mathrm{~m}$ expected at $1630 \mathrm{Z}$ based on meteorology at $1600 \mathrm{z}$. 

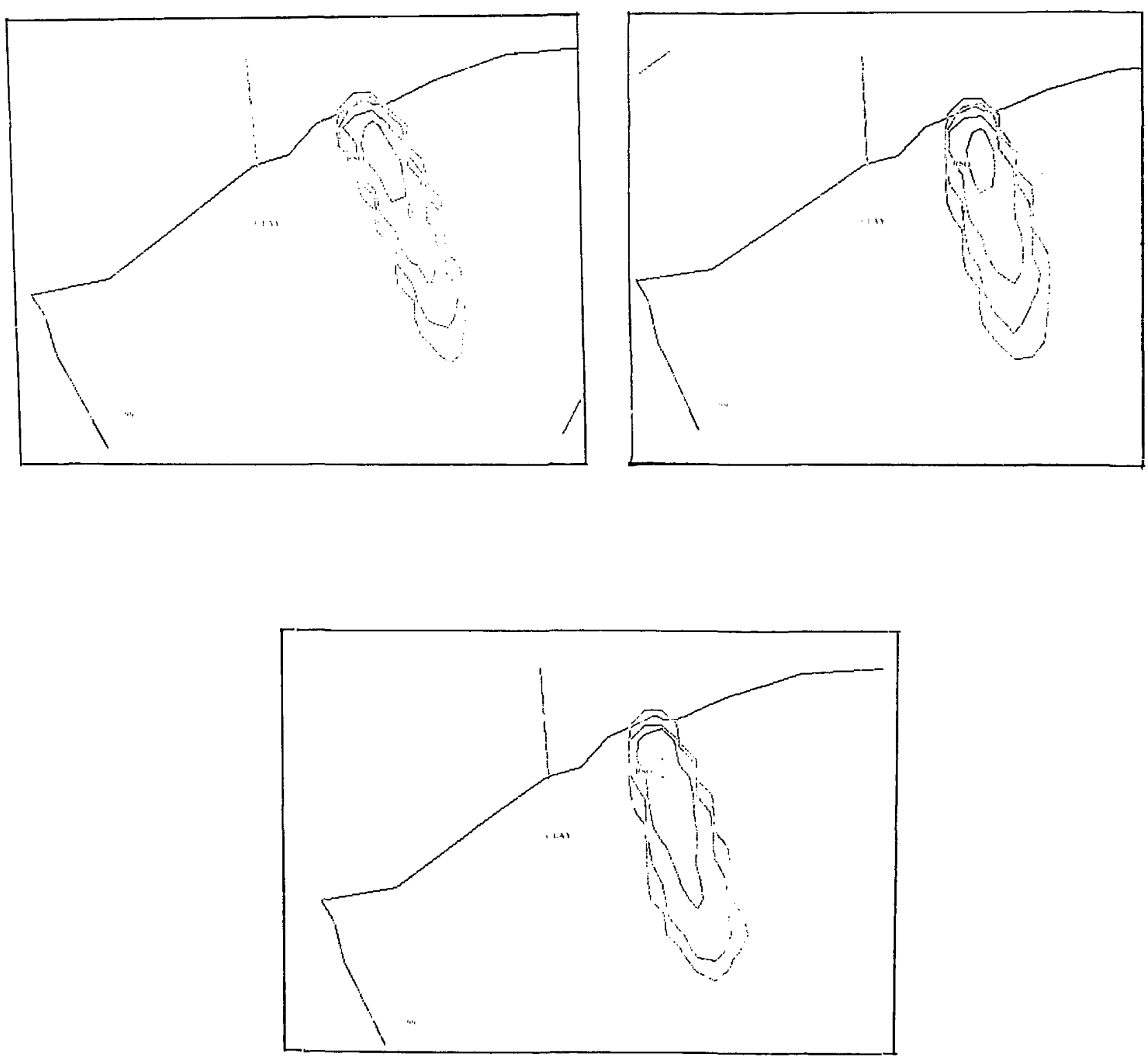

Figure 8. Representative contours of ARAC model calculations during the December 4, 1981, test at Pancho Seco. (a) Integrated Xe-133 air concentrations; (b) integrated Cs-137 air concentrations; and (c) instantaneous air concentrations of I-131. All contours are at $2 \mathrm{~m}$, expected at $1800 \mathrm{Z}$ based on meteorology at $1700 \mathrm{Z}$, due to $a$ unit source rate and calculated by employing the PATRIC code. 

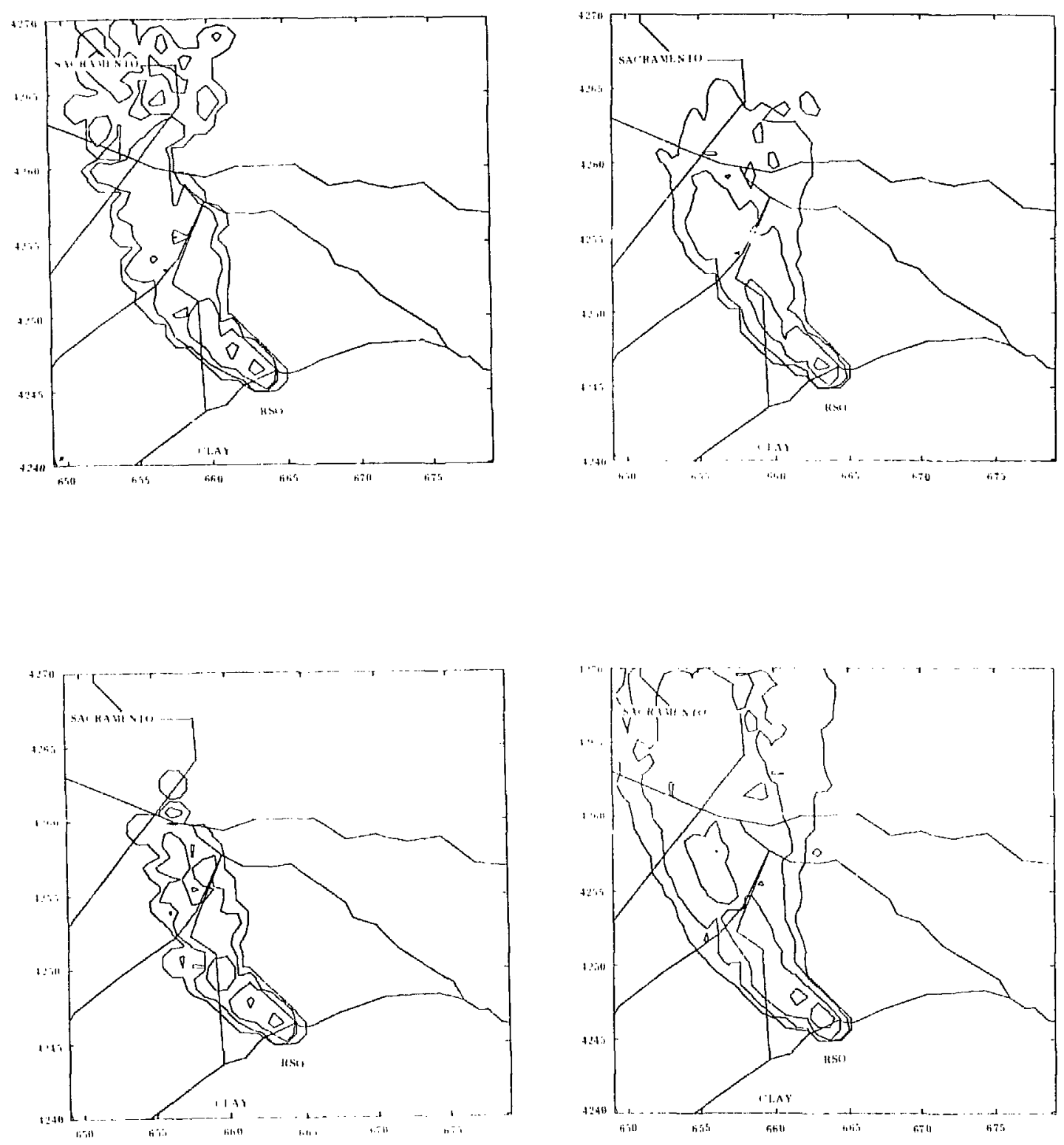

gure 9. Representative contours of ARAC model calculations employing ITHEW/ADPIC codes during the January 19, 1982, test at Rancho Seco. (a) Deposition of I-131 for a unit source rate expected at $1815 \mathrm{Z}$ based on meteorology at $1715 \mathrm{Z}$; (b) integrated $\mathrm{Cs}^{-137}$ concentratinns at $2 \mathrm{~m}$ expected at $1715 \mathrm{Z}$ based on meteorology at $1615 \mathrm{Z}$ for a release rate of $1.0 \times 10^{-3} \mathrm{Ci} / \mathrm{s}$; (c) $\mathrm{I}-131$ deposition forage-cow-milk pathways for a release rate of $1.0 \mathrm{Ci}$ /s expected at $1715 \mathrm{Z}$ based on meteorology at 1615Z; and (d) Xe-1 33 external gamma whole-body dose for a release rate of $1.0 \times 10^{3} \mathrm{Ci} / \mathrm{s}$ expected at $1815 \mathrm{Z}$ based on meteorology at $1615 \mathrm{Z}$. 



Figure 10. Representative contours of ARAC model calculations employing MATHEW/ADPIC codes during the March 3, 1982, Indian Point exercise. (a) Forage-cow-milk pathway deposited by I-1 31 from $1530 \mathrm{Z}$ to $2030 \mathrm{Z}$, assuming a $24 \mathrm{hr}$ grazing period; (b) integrated Xe-133 concentrations at $2 \mathrm{~m}$ expected at $2030 \mathrm{Z}$ based on meteorology at 1900Z; and (c) integrated I-1 31 concentrations at $2 \mathrm{~m}$ expected at $1630 \mathrm{z}$ based on meteorology at $1600 \mathrm{z}$. All contours are calculated using to a unit source rate. 


\section{E. Training Tape}

One of the objectives of this pilot project was to provide a tape of isopleths for use in emergency preparedness exercises. To this end, the staff of ARAC prepared a set of sequential contours utilizing the MATHEW/ADPIC numerical models and meteorological data for October 1, 1981. These isopleths were arranged in order on a tape that could be mounted by the site system user. Once the proper set of instructions was employed, the contours could be viewed by site system personnel. Hence, this tape could be used either to train new personnel in the interpretation of ARAC products or, by timing the advance of the visually displayed contours, to simulate an emergency response exercise. The tapes were delivered on October 24, 1981. Table 4 gives instructions for mounting and operating the tapes and explains the isopleth information contained thereon. Figures 11 (a) through $11(d)$ give representative contours contained on the tape. The contours are, respectively, for integrated air for I-13l and Xe-133, instantaneous air for Xe-133, and ground deposition for $\mathrm{Sr}-90$. All are normalized with a unit release rate.

TABLE 4. Training tapes.

\section{INSTRUCTIONS}

Mount tapes: OTO on drive O and DTl on drive 1

Boot system: Set date/time for 1 October 1981, $0855 \mathrm{Z}$

(The contours have a date of $10 / 1 / 81$ )

\section{INFORMATION}

The first met data will appear at 0900 and will be collected every 15 minutes (displaying Gaussian) until $0845 \mathrm{Z}, 2$ October. If the system is not rebooted, the cycle will repeat.

Contours are available one hour after the observed time for the hourly calculation. That is, the 0900 contour is available from 1000 until 1059. If an hour is missed, the contour cannot be retrieved unless the system is rebooted, or the 24-hour cycle is repeated. The last contour set is for the observation time of 2000 .

The contours are for integrated surface air-ADPIC for I-131 and $\mathrm{Xe}-133$, instantaneous air-ADPIC for Xe-133, and ground deposition-ADPIC for ${ }^{131}$ and $\mathrm{Sr}-90 \mathrm{r}$, normalized with a unit release rate.

To receive a contour set: Type 10 and return when in the main menu. This will activate the communications simulator, and the contours for that hour will be sent to the simulated site tape.

Except for item 10 being different and items 11 and 12 being disabled, all other functions of the site system are available.

The system may be rebooted at any time to restart the training session. 

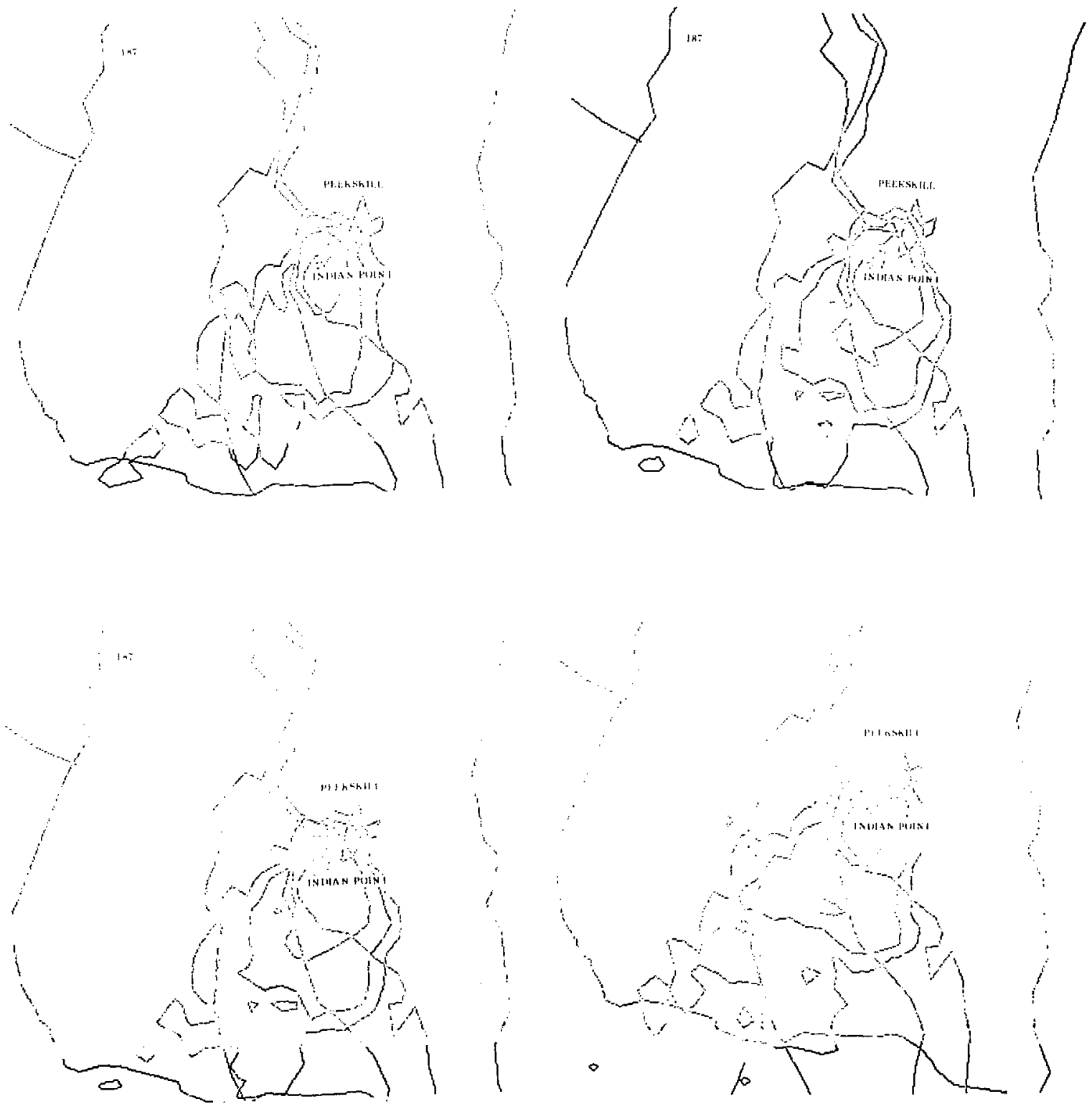

Figure 11. Representative contours of ARAC model calculations using the MATHEWTADPIC codes displayed on the emergency preparedness training tape employing meteorological data for October 1,1981 . (a) In tegrated I-131 concentrations $2 \mathrm{~m}$ at $1900 \mathrm{Z}$ based on meteorology at $1800 \mathrm{Z}$; integrated Xe-133 concentrations at $2 \mathrm{~m}$ at $1900 \mathrm{Z}$ based on meteorology at $1800 \mathrm{Z}$; instantaneous air concentrations of Xe-133 at $2 \mathrm{~m}$ at $2000 \mathrm{Z}$ based on meteorology at 1900Z; and (d) deposition of Sr-90 at $1900 \mathrm{Z}$ based on meteorology at 1800Z. All contours are calculated using a unit source rate. 


\section{F. Ginna Nuclear Power Plant Accident}

As part of this project, ARAC will respond to the pilot project sites in California and New York should an actual nuclear accident occur. On January 25, 1982 , a tube ruptured in the "B" steam generator at the Robert E. Ginna nuclear generating plant near Rochester, New York. During the event, an unspecified number and amount of radionuclides were released into the atmosphere. The operating utility, Rochester Gas and Electric Corp. estimated after the accident that approximately $480 \mathrm{Ci}$ of radioactive material had been released.

At 1620Z ARAC was notified of the accident, via the DOE EOC, by a Department of Energy official. The actual event began at approximately 1435Z, with the site emergency being declared at about $1545 \mathrm{Z}$. Within seven minutes of notification, the ARAC staff had identified the locale and obtained meteorological data; they were also able to prepare a CPS Gaussian calculation within 27 minutes of notification. Since the Ginna NPP site was not already serviced by ARAC, local topography had to be generated, which took approximately 45 minutes. The first ADPIC calculations were transmitted to the New York State Office of Emergency Preparedness from $1820 \mathrm{Z}$ until $2130 \mathrm{Z}$. Contours representative of those transmitted are shown in Figs. 12(a) through 12(d). All calculations were based on a unit release rate. Figures $12(a)$ and $12(b)$ give instentaneous air concentrations for Xe-133 at 2 $\mathrm{m}$, based on observed meteorology for $1400 \mathrm{Z}$ at $1500 \mathrm{Z}$ and $1600 \mathrm{Z}$, respectively. Figures 12(c) and 12(d) give integrated Xe-1 33 concentrations for $1500 \mathrm{Z}$ and $1600 \mathrm{Z}$, respectively, based on meteorological observations at $1400 \mathrm{Z}$.

\section{Evaluation}

All participants in this pilot project were asked to submit formal written critiques after the completion of each exercise. These critiques were used by the ARAC staff to improve future testing, to communicate necessary information to the participants, and to improve future system components. The formal critiques, ARAC staff evaluations, and informal communications between ARAC personnel and pilot project participants contributed to the base of experience evaluated and discussed within this section.

\section{A. Installation}

The efficiency and speed with which the system was delivered, uncrated, and initially installed by the manufacturer, as well as the ordering and installation of the meteorological interface, varied widely among the organizations involved in this pilot project. A number of institutional delays discussed in section III, paragraph B cannot be influenced by ARAC and are unavoidable since each organization has its own process of review, decision-making, purchasing, etc. However, realization of these factors could mitigate delays and misunderstandings in the future. The time each organization will require to complete its decision-making, engineering, and ordering processes must be considered before initiation of ARAC service to keep time delays to a minimum. This would be accomplished by communications, documentation, and follow-ups on timelines and engineering requirements between ARAC and the site system user staff. 

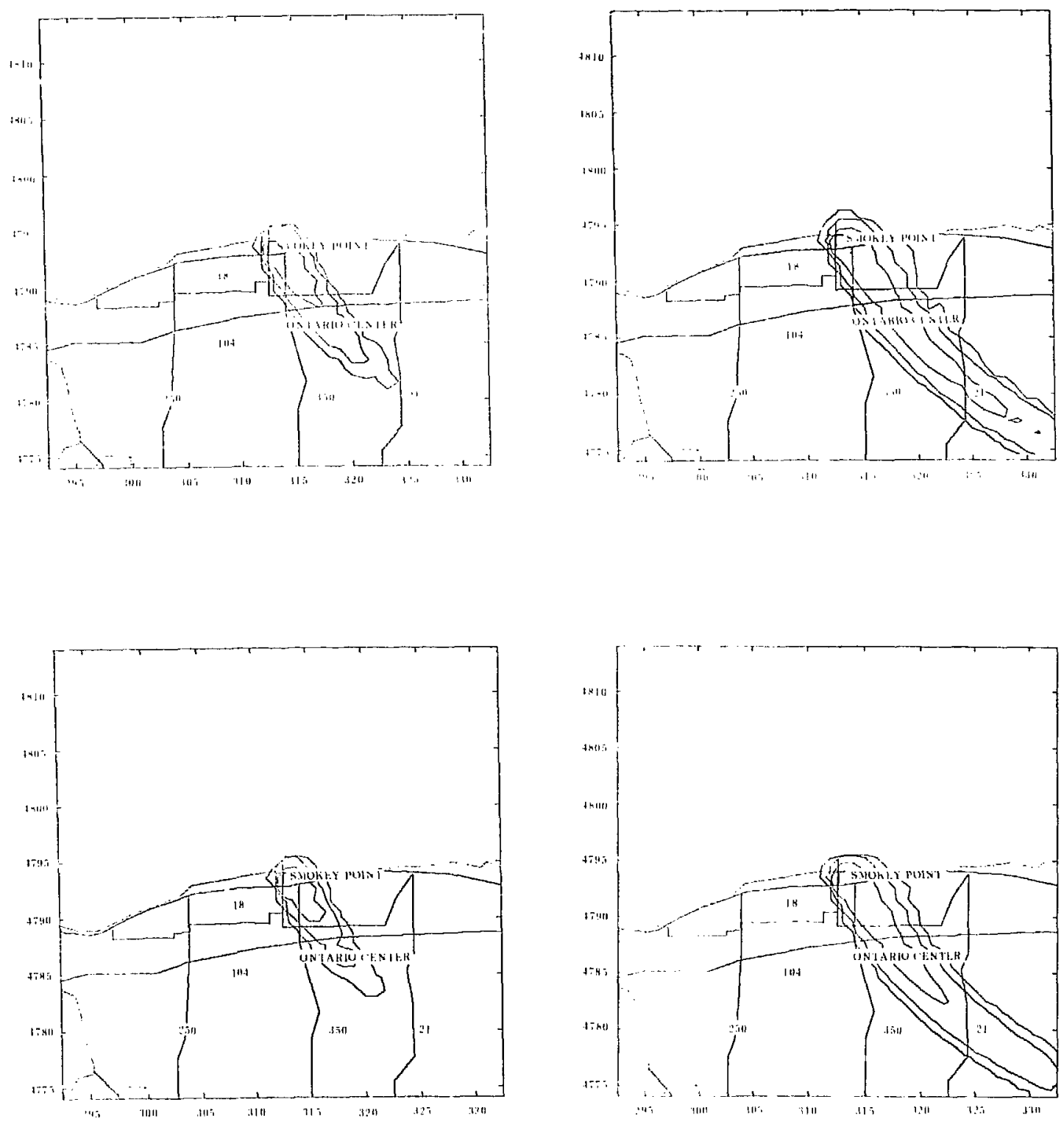

Figure 12. Representative contours of ARAC model calculations employing MATHEW/ADPIC codes transmitted during the January 25, 1982, Robert E. Ginna nuclear power plant accident. (a) Instantaneous air concentrations of Xe-133 at $2 \mathrm{~m}$ at $1500 \mathrm{Z}$ based on meteorology at 1400Z; (b) instantaneous air concentration of $\mathrm{Xe}-133$ at $2 \mathrm{~m}$ at $1600 \mathrm{Z}$ based on meteorology at $1400 \mathrm{z}$ (c) integrated Xe-133 concentrations at $2 \mathrm{~m}$ at $1500 \mathrm{Z}$ based on meteorology et 1400Z; and (d) integrated Xe-133 concentrations at $2 \mathrm{~m}$ at $1600 \mathrm{Z}$ based on meteorology at $1400 \mathrm{Z}$. All calculations are based on $a$ unit release rate. 


\section{B. Operation of the ARAC System}

At the completion of testing, the site system users evaluated the ARAC system overall as a valuable emergency response tool for nuclear power plant accidents. Some individual evaluations of ARAC system components are discussed below under Communications, Models, and Staff.

\section{Communications}

There are two aspects to communications by site system users: (1) the interaction of the site system operator, via the keyboard, to obtain such menu information as Gaussian plots, and (2) the interaction of the site system, via the console with the ACF, to send and receive messages and to receive contours.

The four-test series exercises described in detail in section III, paragraph C, enabled all site system users to become proficient at obtaining menu information, via the keyboard, by the end of the testing program. However, because of the age of the hardware, certain problems persisted throughout the project. For example, the printer broke down or the joy stick became inoperative. DEC representatives were called in to repair these problems under service contracts established by each site system user. The design of the next-generation ARAC system, which will utilize state-of-the-art hardware, will remedy these problems.

Communications between the site system users and the ACF presented problems associated with message interruptions that disturbed the transmittal of messages and contours. This software problem will be eliminated in the ARAC system now bring designed.

The communications at the start of an exercise are generally initiated by the utility to the ACF indicating the nature of the "emergency." The $f$ CF transmits contours first to the state and then to the utility. This communicat:or. ietween the state and the utility is prescribed by each state's emergency preparedness plans. Some confusion about the procedures existed early in the testing program, but was completely cleared up by the completion of all exercises.

\section{Models}

The three numerical models used to determine concentration contours during this pilot project were the Gaussian, PATRIC, and MATHEW/ADPIC, all of which are described briefly in paragraph $C$, section I.. The Gaussian model is generated directly by the site system user, employing meteorological data obtained from the meteorological tower of the NPP. PATRIC was used in exercises 1, 2, and 3; MATHEW/ADPIC calculations were performed during exercise 4, the FEMA/Indian Point exercise on March 3, 1982, and during the Ginna accident on January 25, 1982. The models employed have been evaluated with respect to accuracy in past experiments. In particular, MATHEW/ADPIC has been compared successfully against measurements in four field-diffusion experiments. An evaluation of the models herein is thus concerned with such factors as availability, timing, and comprehensibility.

The Gaussian model is available at all times at the site system, using data from utility meteorological tower data that is updated every $15 \mathrm{~min}$. During the standard 40-hour work week, the more sophisticated MATHEW/ADPIC model contours should be available approximately $45 \mathrm{~min}$ after the ACF has been notified of an accident. Sets of contours are typically transmitted each hour. However, 
hardware breakdowns and communications interruptions delayed the transmittal of contours during some exercises. Further, the time required to plot the contours frequently consumed a large frastion of the time between hourly transmissions, eliminating the possibility of transmitting many messages. These problems have been considered carefully in the design of the next-generation ARAC system.

In general, the information transmitted to the site systems by the ACF was evaluated positively by the users. Project participants commented on the value of the contours in the event of an accident or in an emergency preparedness exercise. Additionally, user suggestions to make the contours more readable and understandable were incorporated into the ARAC system.

3. Staff

The staffs of the ACF and site facilities are an integral part of the ARAC system. The ACF staff is comprised of meteorologists, physicists, computer scientists, and electronics engineers, while the site system staff is generally made up of health physicists and computer scientists with varying knowledge of various transport-diffusion codes. Because of it was this variation in knowledge, the training had to be tailored for a wide range of needs. This was accomplished through formal orientation meetings and exercises and through informal communications between all personnel. Throughout, project has been marked by the cooperation of all participants in executing, completing, and evaluating ARAC system use at the NPPs and their associated state of fices.

\section{Design Implications for the Next-Generation ARAC System}

The experience gained in this pilot project has been of great value in designing the next-generation ARAC system, which is expected to be operational by mid FV 1984. The next-generation ARAC system is expected to include state offices, as appropriate. The current site system performs basically five distinct functions: (1) meteorological data collection and display, (2) local Gaussian plume projections, (3) transmission of meteorological data to the ARAC center, (4) transmission and display of regional model contour products from the ARAC center, and (5) a user-to-ARAC operator message facility. Of these, functions (2), (4), and (5), together with some additional functions, will be retained in the new site system.

The collection and transmission of meteorological data from the site to the ARAC facility will be accomplished by means of a separate computer that conforms to the standards for data collection and reporting set forth in NUREG-0654. The site system will have access to this data either by direct access as a user of the meteorological system or indirectly by way of the ARAC center or network gateway. The user need not know actual source of the data in this type of network. The site system will retain the capability to generate local model predictions based on local or user-specified meteorological data.

The model may be either an enhanced Gaussian or a range of other model types up to and including direct access to MATHEW/ADPIC-type models. These codes will be executed either at the ARAC facility or locally, depending on the type of code used and the configuration of the user's site system. The physical site system may consist of anything from a simple graphies terminal and hardcopy unit 
that can request and display data as generated by the ARAC facility to a VAX-class machine with multiple graphics workstations capable of generating complex modeling information locally. Again, the user need not be aware of the type of system he is on since the same functionality will be available to all users. A typical site may have only a small meteorological data collection computer and a simple graphics terminal to request and display data, while state or regional response center may well have a VAX-class machine with local modeling capabilities. It will be up to the user to decide the speed and usage requirements for his site to determine the level of system required. Typical installation costs may run from a low of about $\$ 25 \mathrm{~K}$ up tc $>\$ 200 \mathrm{~K}$ for a large multi-user regional response system. One advantage of this type of network is that the computing resources may be spread over a large area, giving improved reliability and response to all users. In addition, the user is basically in control of the information he receives. For example, there is no need to send six regional mociel contours to a user who only wants one, which takes time and increases confusion at the user's end. In an emergency, the ARAC facility will make availab'e a broad range of products from which the user can select. During routine operations, when the user may want a simple advisory calculation, he may select the type and parameters directly without direct intervention of the ARAC staff. 


\section{References}

1. M. H. Dickerson, and R. C. Orphan, Atmospheric Release Advisory Capability, Nucl. Safety, $\underline{17}(3), 281-289$ (1976).

2. C. A. Sherman, MATHEW: A Mass-Adjusted Three-Dimensional Wind Field Model, Ph.D. thesis, University of California, Davis, California, 1978a. Published as Lawrence Livermore National Laboratory Report UCRL-52479.

3. C. A. Sherman, A Mass-Consistent Model for Wind Fields Over Complex Terrain, Lawrence Livermore National Laboratory, Livermore, Calif., UCCRL-76171, Rev. 3. Published in J. Appl. Meteor., 17(3), 312-319 (1979b).

4. R. Lange, P. H. Gudiksen, and K. R. Peterson, ADPIC: A Three-Dimensional Computer Code for the Study of Pollutant Dispersal and Deposition on the Regional Scale, Lawrence Livermore National Laboratory, Livermore, Calif., UCRL-76492(1975).

5. R. Lange, ADPIC: A Three-Dimensional Particle-in-Cell Model for the Dispersal of Atmospheric Pollutants and Its Validation Against Regional Tracer Studies, Lawrence Livermore National Laboratory, Livermore, Calif., UCRL-76170, Rev. 3. (1978). Published in J. Appl. Meteor., 17(3), 320-329 (1978a).

6. R. Lange, PATRIC: A Three-Dimensional Particle-in-Cell Sequential Puff Code for Modeling the Transport and Diffusion of Atmosphric Pollutants, Lawrence Livermore National Laboratory, Livermore, Calif., UCID-17701 (1978b).

7. K. R. Peterson, T. V. Crawford, and L. L. Lawson, CPS -- A Continuous-Point-Source Computer Code for Plume Dispersion and Deposition Calculations, Lawrence Livermore National Laboratory, Livermore, Calif., UCRL-52049 (1976).

8. L. C. Rosen, and R. C. Orphan, ARAC Feasibility Study for the NRC Phase I: Final Report, Lawrence Livermore National Laboratory, Livermore, Calif., UCID-18315 (1979).

9. B. S. Lawver, ARAC Site Terminal Installation Guide, Lawrence Livermore National Laboratory, Livermore, Calif., UCr!)-18569 (1980).

10. E. Cassaro, and L. Lomonaco, Operators Guide: Atmospheric Release Advisory Capability (ARAC) Site Facility, Lawrence Livermore National Laboratory, Liver more, Calif., UCID-18050 (1979). 


\section{Appendix A. Critique of Tests}

\section{Comment 1}

In accordance with the 'Expected Outcome' in test \#2 of the Indian Point/ $\mathrm{N}$. Y. State/ARAC training program, we are forwarding a written critique of the exercise. Four operators were present at our ARAC facility during tests \# 1 and \#2. Overall, the tests to date were of significant benefit in that all operators have been given ample opportunity for "hands-on" experience with the site system when it is on-line to the ACF. These exercises have also provided us with the opportunity to determine some areas in which the service provided by the ACF could be optimized. These areas fall into two general categories: (1) communications with ACF, and (2) information provided with contour plots. Specific descriptions of these areas are listed below.

\section{Telephone Communications with ACF:}

All of our operators have noticed that communications initiated from the ARAC site terminal to ACF are very frequently interrupted by messages sent from ACF. Presumably the same problem occurs at the ACF terminal. The result is that messages initiated from our end are transmitted in incomplete or garbled form. During the last two exercises, verbal telephore communications had to be established in order to complete messages. Would it be possible to establish some sort of software controlled protocol that would prevent or delay message interruptions? For example, a message transmitted by a sender could be ended with a control character. The operator at the receiving end would observe the message and, for example, a blinking square next to the word "send." The blinking square would indicate that the receiving operator has 30-45 seconds in order to transmit a reply without being interrupted by new messages from the original sender.

The operators have also noticed that when they attempt to view transmitted contours while the system is on line to the ACF, the display is periodically interrupted by a "message from ACF ..." signal on the screen. Since the operator tends to feel that the message is more important than viewing the contours, the delete key is not employed. The result is, however, that the system appears to redial ACF - and no message from ACF appears on the screen. Presumably, no message has been sent by the ACF. Can your sof tware be modified to eliminate this problem? For example, the PDPl104 must have some type of interrupt function that could be used to print messages only on the keyboard terminal when the delete key is activated.

Finally, some of our operators also asked whether it might be advantageous to have an additional option in the main menu that would allow dial up terminal communications between the N. Y. State and Indian Point facilities.

\section{Information Provided with Contour Plots:}

a. Description of Output. All of our operators agreed that a compact description of the numerical and graphical outputs for the submenus and the types of calculations available in both the site and regional model options should be made 
available to the site facility. The most useful form in which their description could be presented would be one (or two) 8-1/2" $\times 11^{\prime \prime}$ sheet(s) containing flowcharts detailing all of the information available in each submenu item. These sheets could then be posted within easy access of the ARAC terminal, and would serve as a handy reference to assist operators in interpreting the transmitted contours.

b. Graphics Output. The operators also agreed that it would be extremely useful to have the following additional information printed and plotted with the contour plots for both regional and site models.

- a line scale for distance marked in $\mathrm{km}$

- time since release started (if known)

-- release rate (if known)

- north/south indicator

-- wind direction and speed

- dose conversion factors (if dose contours transmitted)

-- symbols used for contours in the regional model should be placed next to corresponding concentration or dose.

c. Numerical Output. Another question discussed was whether numerical printouts of the following information could be obtained on our printer terminal as an option included in submenus:

- meteorological data

-- center line value for the site model as a function of distance from source (e.g. the CPS code)

-- normalized concentrations for a grid coordinate system encompassing the contours for the site model or regional model calculations.

The discussion above is based on what we would consider the ideal system and is of course independent of our budgetary, manpower and hardware constraints. We hope that our critique here may be of some use to you in improving the system.

\section{Comment 2}

In accordance with the agreement for completion of test $\# 3$ for the Indian Point/N. Y. State/ARAC training exercise of September 18, 1981, we forward this written critique of the exercise. The three operators present at the State ARAC facility during this test observed a number of problems throughout the exercise. The preblems are described within three general eategories: (1) communications with Indian Point, (2) communications with the ARAC Central Facility (ACF), and (3) time required for plotting transmitted contours.

\section{Communications with Indian Point:}

On September 17, Linad Lamonaco, of the Indian Point staff, informed us via telephone that the exercise would start at 0800 on September 18 and that should would call again at that time to relate the specifics of the scenario for the release. All three operators for the NYSDH system were at their post by 0745 on the morning of the exercise. However, no contact was made with the NYSDH facility by Indian Point during the entire exercise. The result was that the NYSDH facility had no knowledge of critical data such as release height, source release rate, 
nuclides released, time of onset of release, projected duration of release, etc. It was therefore unclear as to what exactly was happening at Indian Point during the exercise. An effective means of, and protocol for, comm. inication must be eastablished between Indian Point and the NYSDH facility. As mentioned in our critique of previous exercises, an additional option should be provided in the main menu to allow dial up terminal communications with the Indian Point site facility.

Although the exercise called for contours to be first transmitted to Indian Point, it should be noted that it is the State which must make critical decisions with respect to evacuation or sheltering of people living in the path of the plume and should be given priority in data transmission and communication.

\section{Communications with ACF:}

The interrupt function, as described in the previous critique, once again gave the operators problems during this exercise. No mention is made of this function in our site operator's manual. We therefore assumed until after the test that the interrupt message actually meant that a massage was being transmitted from the ACF. We later learned that the interrupt is simply a periodic "hand shake" between computers. Our operators, therefore, did not activate the delete key to cancel the interrupt. It was also noted by all three operators on the day of the test that whenever the delete key was depressed to override an interrupt during a plot of a contour, the site system would "crash." (Test runs on 9/23/81 failed to reproduce this effect.) As the time required to complete a $100 \mathrm{~m}$ scale plot is on the orde of 2-2.5 min., the instinct at the time was to terminate telephone communications with ACF so that contour plots could be completed prior to the next contour update. Conversations with George Greenly on $9 / 23 / 81$ revealed that terminating telephone communications in such a manner was troublesome for the ACF. This practice will be avoided by our operators in the future. If the telephone link is to be terminated, the operators will notify ACF via telephone or terminal.

\section{Time Required for Plotting Transmitted Contours:}

Starting from the main menu, it requires a little more than 5 minutes to complete a plot (including 1 to 2 minutes for choosing options on menus). If, as in the exercise of September 18, many contours are sent from ACF during each hourly update, it is evident that most or all plots must be completed before the next update or contours will be lost from the queue. It was clear from text \#3 that more practice at rapidly plotting contours is required by our operators. However, messages from ACF indicating the appropriate scale and release location for the transmitted contours would be most helpful. It might also be advantageous if: (1) the queues for contours could be expanded from 6 to 10 , and (2) the submenu for regional calculations be expanded to include a category for dose contours.

\section{Comment 3}

Three operators were present at our ARAC facility for the $9 / 25 / 81$ exercise. In general, this test, at least in Albany, went more smoothly than the previous three exercises. State operators have become more familiar with communications and plot systems of the terminal as the training program has progressed. All contours 
transmitted from the ACF were printed in sufficient time to prevent them from being lost as new contours were received. R were also provided to the State facility by Linda Lomonaco at Indian Point.

However, the test was not without incident. The State site system crashed twice during the exercise. One crash occurred at $1432 Z$ and the other at $1550 Z$. Both crashes were associated with the transmission by ACF of contours to the State facility. Prior to the first crash, the following error messages were printed on the terminal:

? ERR 61

IN ROUTINE"CRC

FROM ROUTINE "SEND

F ROM ROUTINE "XPRO

FROM ROUTINE "ACFCOM
"LINE?

"LINE?

"LINE?

"L

Prior to the second crash the following error message was printed continuously (about 50 times).

\section{? ERR 4}

IN ROUTINE "BLDSPF" LINE?

Perhaps these error messages may be useful in debugging the ACF system.

As discussed in the previous cirtiques, the operators again felt quite negative towards the interrupt function "Message from ACF ...". The primary reason is that the operator never really knows when a message is to be transmitted by ACF. The basic problem was summed up by one operator as: "The interrupt leaves you two choices; one being that the operator can allow the system to default and not accomplish any contour prints. The other is to continually override the default and not receive any messages from ACF." If some way could be found to eliminate the necessity for manual override of this interrupt, it would be most helpful to the site operators. If the interrupt cannot be eliminated, would it be possible to transmit a character at the end of the interrupt message to indicate that a message is actually being relayed from $\mathrm{ACF}$ ?

It is apparent from the last fol: exercises that the operator's primary duty on the ARAC terminal is to print as many contours as possible before the next update -- there is very little time available, in the case of hourly updates, for the operator to do anythig else. The process of printing the contours could be made more efficient if the AC:F were to transmit release location and appropriate contour scales before sending contours (see previous critique for test \#3).

During the updates provided by Indian Point throughout the exercise, it appears that the power plant was receiving priority in communications, priority in establishing which dose contours were to be transmitted, and priority in obtaining contours. As in the previous critique, it should be pointed out that it is the State that must make the critical decisions regarding the impact of an actual release on its population and environment. It is therefore important that the State's ARAC terminal be given these priorities rather than the plant. 


\section{Comment 4}

The following is the Power Authorities informal critique comments for the three ARAC exercises for Indian Point.

1. September 10, 1981, 9:00 a.m. Familiarization Exercise

Indian Point was made aware that we were unable to "set emergency," i.e., we were unable to initiate site system to ACF communications. Other than this, the exercise went well, contours were received and we certainly felt more comfortable in using the system than prior to the exercise.

2. September 18, 1981, 8:00 a.m. PATRIC Run

Again, the problem with setting the emergency occurred and to initiate communication the ACF had to call IP-3. Several points were noteworthy for this exercise.

a. IP-3 learned quite a bit more about the ARAC codes from this exercise.

b. Indian Point feels we should be getting the ARAC outputs first, rather than $\mathrm{N}$. Y. State receiving the information first.

c. It was learned that we cannot use the site system and receive contour information at the same time. This results in the site system being unusable while the contours are in transit and therefore not helpful to the assessment team during that time period.

d. The "real-time" availability of contours was delayed a long time, approximately 2 hours. We realize this was because LLNL had problems with computers, but, nevertheless, the time delay should be noted.

3. September $25,1981,8: 00$ a.m. MATHEW/ADPIC

Again, the communication between IP and the ACF portion of the test was a problem and is being looked into and should be corrected soon. This test went well, however, it was very long and time consuming. Again, a part of the problem was not being able to use the system when the contours are being sent or received. The problem further develops if we are using the system and you send a message and contours are coming, neither the message nor the contours will be received. As you see, this will put a huge time delay factor into the operation.

A general comment would be the printer is much too slow and inefficient. There are much faster printers on the market, such as the ones used for the CDC 7600s at LLNL. Perhaps these should be investigated.

. Thank everyone involved for their help in teaching all of us the system and I'm sure we'll be in contact soon. 


\section{Comment 5}

Some problems we encountered during test \#2 on ARAC are as follows:

1. The system went into the "send" mode in the middle of contour generation for type 5 contour \# 3 .

2. The system re-booted in the middle of contour generation for type 6 contour \#1.

However, we wers able to generate the contours by starting over again from the menu.

Our people have been practicing using ARAC so that they may become more familiar with its operation, but feel they could use more specific instructions prior to the tests so they'll have a better idea of what to do. Any help you could give us in this area would be appreciated.

As to the problems on our end, we're still trying to get PT \& $\mathrm{T}$ to come out and fix our modem so our ARAC computer can call out to the ACF. Also, our engineering department is working on the connection between the ATI-16 interface and the state's modem; it may still be possible to complete tests 3 and 4 by November 15 if all goes well. In addition, the changes to our meteorological tower instrumentation were completed on October 22 and appear to require some sof tware changes. Attached is a copy of the meteorological data as seen by ARAC. I have been in contact with Tom Green about this.

We continue to have hardware problems regularly, the latest problem being the CRT display.

\section{Comment 6}

The following comments apply to test \# 3 of the demonstration program:

1. The system re-booted for some reason after the first five contours were received. This occurred at 0955 , af ter starting to send contours at 0945 . At 1013 and 1015, communications with ACF were cut of for an unknown reason, but were re-established both times by ACF. We did nothing at the terminal to cause this. At 1017 we received the sixth contour.

2. Between 1017 and 1100 we tried to generate some of the contours received, but encountered several problems:

a. It took us some time to get the proper coordinates into the regional map (at $25 \mathrm{~km}$ ) so that RSO would be centered on the display. It was at Hwy 99 on the regional map.

b. We kept receiving a flashing display on the CRT saying that ACF was trying to communicate with us, so we stopped trying to generate contours and waited for the communication, but none was received; we would then have to start over again trying to solve our coordinates problem and generate contours. 
c. The tape was slower than usual, since it was an older tape that had been modified with new data.

Because of the above problems we didn't get any hard copies of the first six contours done before we began to receive an additional six contours at 1100 .

3. We were sent 8 contours of type 4. We lost the first two since there is only room for six on the type 4 menu.

4. On the type 4 contours were whole body doses are calculated, it is unclear to us if the dose attributed to Cs-137 inhalation, is that received up to that point in time on the display, or if it includes projected exposure due to retention of cesium in the body. We would appreciate an answer on this question as soon as possible.

5. We feel it would be helpful if you gave the units for "W.B. DOSMAX." We assume it is given as "mrem" but, under emergency conditions, giving the units of exposure minimizes confusion.

We are looking forward to tes" \# 4 on Friday.

\section{Comment 7}

Test \#3B of the ARAC demonstration program went well. We were able to generate all contours received.

We were still using the same tape we had for test \#3A; things went slower than they would have if we'd been successful in rebooting the system with the tape brought by Tom Green that morning. There appears to be a problem with the tape drives and/or the new tape we tried to install. Since the test, Digital has worked on the tape drives, but we do not now have a tape that will reboot the system. We have discussed this situation with several people at the Lab. Our system has been down since December 6 .

The system rebooted only once during the time you were sending us contours.

We should be ready for test \#4 in January once we get another tape and iron out any problems we might still have with the drives.

\section{Comment 8}

Some comments applicable to test \#4 on ARAC:

1. Before touching the console for the first time, the system robooted for no apparent reason. This was at $8 \mathrm{AM}$ when we were preparing to initiate the exercise. The system rebooted again for no obvious reason, while communications were established, at the following times: 0832, 0906, 1000,1012 , and 1025 PST. 
2. At 0945 we received a call from ACF asking if we had any problems with the system since the second contour couldn't be sent to us. There was nothing wrong with the system as far as we could tell. While on the phone with ACF, we began receiving contours again, without having done anything to the system.

3. At 0950 we tried to generate contours, but everything stored on the menus was garbage; we rebooted and that fixed the problem.

4. We had trouble shrinking the regional map to the $50 \mathrm{~km}$ scale and couldn't escape from the generate contours' mode without rebooting. A call to $\mathrm{ACF}$ pointed out what we were doing wrong and we had no further problems with this.

5. At 1042, we lost communication when we attempted to communicate with ACF (10 on the menu). We re-established communications with no problems.

6. After the exercise, we discovered that the meteorological data for $1815 \mathrm{Z}$ was missing when we unsuccessfully attempted to print out a Gaussian (8 on the menu).

7. As mentioned in an earlier critique, it would be helpful if WBDOSE-MAX and INFANT THMAX units were given on the display to minimize the possibility of confusion under emergency conditions.

\section{Comment 9}

Comments on the December 4, 1981 drill:

1. Joy stick wouldn't move the tracking cross horizontally; vertical okay.

2. Plotter paper; where does it come from and who puts in?

3. Can we get the sample height at one meter instead of two?

4. When dose readings are provided, are they 24-hr, 50-year or what?

5. Had to re-boot about 1015; no problem. Need a line regulator to get rid of blips which are causing us to drop out and having to re-boot.

6. More documentation on the system to include descriptions of programs, labels or identification of the menu, including units. A chart or reference card at the console would fill the bill.

7. Getting data back from the Center, who gets it first and why?

8. It is difficult to know when we are to operate the keyboard to communicate and when no to do so. Procedures?! Brevity is good, but sometimes it is confusing if overdone. The present system is probably okay for those terminals which are frequently used and the procedure has become routine. But, since we will use the terminal infrequently, a little more detail, idiot-proof instructions are required. 
9. In Type 5 the locale of the contours seem wrong; misplaced, unless it is assumed the plume come to ground a distarice from the plant.

As you know, Items 1 and 5 have been corrected. ltems $3,4,6$ and 8 should be considered in your redesign of the next generation equipment.

ln regard to the new generation, I am sure a more compact unit is being considered. We would like to see more detail when we move the maps to smaller scales. l don't think color is as important in a plotter as speed, clearity and sharp detail. We would also like ARAC to continue to be even more readily adaptable than it is now. Your plan to offer ARAC users several choices for site terminals that provide a spectrum of capabilities frum simple terminal/hardcopy to high resolution color graphics is good.

You should provide 24-hour service and faster turn around for the programs run on the 7600 s.

\section{Comment 10}

The following comments include our overall assessment of ARAC as well as those of the last exercise.

One of the most of ten mentioned complaints is the seeming isolation from the ARA C center. Communication needs to be easier and quicker through the keyboard or other means.

We find it takes too long to get from the menu to what is selected. It would be desirable to get more detail when map sizes are reduced. It should be possible to enter source terms and conversion factors and get direct readouts in dose or dose rate.

In the last exercise, we had the following problems:

1. The wind data was questionable. We found later there was a problem with on-site equipment for getting wind data.

2. In the Gaussian mode the regional map kept coming up instead of the site map. The detailed site map was available. (This problem has not yet been solved.)

3. Communications with the Center was awkward.

In general, we feel ARAC is a valuable tool for that which it was designed and if it is updated to the fullest extent possible, it will continue to be a valuable resource for us. We also urge you to keep in mind we, as well as others, will use it for other emergencies than nuclear power plant releases. Indeed, its use in hazardous materials accidents could by far outweigh its utility for nuclear power plant accident assessment. In other words, continue it as an atmospheric release advisory capability.

$95 \mathrm{E}$ 


\section{DISC I AINItK}

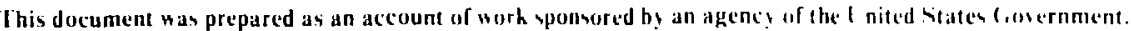
Veither the I nited States Government nor the L niversity of California nur ans of their employech, mahes any warranty, express or implied, or assumes any legal liahility or responsihility for the accuracs. completeness, or usefulness of any information, apparatus, product, or process disclosed, or represents that its use would not infringe privately ouned rights. Reference herein to any specific commercial products, prucess. or service by trade name, trademark, manufacturer, or otherwise, does not necessarily constitute or imply its endorsement, zecommendation, or favoring by the L'nited States Government or the I'niversity of California. The views and opinions of authors expressed herein do not necessarily state or reflect those of the I nited States Government thereof, and shall not be used for advertising or product endorsement purposes.

This report has been reviewed by Lawrence Liverinore National Laboratory for the Federal Emergency Management Agency and has been approved for publication. Approval does not signify that the contents necessarily reflect the views and policies of the Federal Emergency Management Agency. 